\title{
Ebû Hüreyre'nin Fakihliği Meselesi
}

\author{
Adem Çiftci \\ Dr. Öğr. Üyesi, Sivas Cumhuriyet Üniversitesi (ROR ID: 04f81fm77) \\ İlahiyat Fakültesi, İslam Hukuku \\ Assistant Professor Dr., Sivas Cumhuriyet University Faculty of Theology, \\ Department of Islamic Law \\ Sivas/Turkey \\ ademciftci28@hotmail.com \\ ORCID: 0000-0002-9040-2753
}

\begin{abstract}
It is possible to come across the name of Abu Hurairah in many of Islamic disciplines. Although he came to al-Madinah three years before the death of the Prophet (pbuh) he was the one who transmitted hadiths of the Prophet (pbuh) most among the companions. This was sometimes seen odd and caused some accusations. Abu Hurai responded to the criticisms made by some companions about narrating hadiths by insisting on his patience and effort for learning hadiths as follows: "I served Allah's Messenger (pbuh) being satisfied with bare subsistence, whereas the muhajirun (immigrants) remained busy with transactions in the bazar; while the Ansar (helpers) had been engaged in looking after their properties." In additon, there are some reports about the Prophet's (pbuh) appreciation for Abu Hurairah's patience and effort and His prayer for improving his memory. Besides, some companions like 'Abd Allah b. Omar, Zayd b. Thabit, Talha b. 'Ubayd Allah stated that Abu Hurairah was competent and an authority in the field of hadith.

One of the disputes around Abu Hurairah is whether he was a faqih, i.e expert in Islamic law. This issue was brought into question especially by Hanafi jurists within the context of some narrations. Some Hanafi jurists like 'Isa b. Abân explained the nonuse of Abu Hanifa, Abu Yusuf, Zufar and Muhammad b. Hasan the musarrah and ariyyah hadith which are in conflict with the main rule/qiyas as part of that the transmisser of these hadiths, Abu Hurairah was not a faqih. They argued that the condition of being a faqih (fiqh al-rāwī) is sine qua non for using the ahad hadiths that are in conflict with the main rule/qiyas. When the issue is of concern, the jurists who adopt this opinion give example of musarrah hadith and say that musarrah hadith was not used since Abu Hurairah was not a faqih. However, many jurists particularly Abu al-Hasan alKarkhi rejected this opinion and did not accept the condition of being a faqih. Hence, there is no view from the founder imams about the issue. Rather, there are some reports that they used hadiths that are in conflict with the main rule/qiyas. Further they used the first part of the musarrah hadith for dating period of the right of option. Another significant point in this issue
\end{abstract}

The Issue of Abū Hurairah Being a Faqīh

İntihal Taraması/Plagiarism Detection: Bu makale intihal taramasından geçirildi/This paper was checked for plagiarism Geliş/Received: 12 Mayıs/May 2020 |Kabul/Accepted: 29 Temmuz/July 2020|Yayın/Published: 20 Eylül/September 2020 Atıf/Cite as: Adem Çiftci, "Ebû Hüreyre'nin Fakihliği Meselesi = The Issue of Abū Hurairah Being a Faqīh", Eskiyeni 42 (Eylül/September 2020), 825-849. https://doi.org/10.37697/eskiyeni.735998

Copyright $\odot$ Anadolu illahiyat Akademisi/Anatolian Theological Academy, 06050, Ankara, Turkey|www.anilakademi.com CC BY-NC 4.0 | This paper is licensed under a Creative Commons Attribution-NonCommercial License 
is that Ibn Mas'ū $\mathrm{u}$ who has an essential role in the formation of understanding of Hanafī school transmitted this hadith. Nevertheless, the chain of Ibn Mas'ūd is included in Hanafi sources without mentioning the name of transmitter such as "balaghana" or "ruwiya/yurwa" and his name is never mentioned. Additionally, the tariqs of Ibn al-Omar and Anas b. Malik for the hadith of musarrah is never mentioned in Hanafi sources. Nevertheless, there are some jurists who maintained that Abu Hurairah was one of the faqih companions and objected the idea that he was not a faqih. Taking into consideration these two approaches, it seems that there is no uniformity within Hanafi school for rejecting or accepting the condition of being a faqih.

Historical and biographical sources qualify Abu Hurariah as faqīh and mujtahid. Besides, Omar al-Khattab sent him to Bahrayn to deal with jurisdictional transactions and later appointed him as governor here. This shows Omar's reliance on the competence of Abu Hurariah in the field of fiqh. Likewise, there are some fatwas (legal opinion) belong to Abu Hurairah which correspond with fatwas of leading companions or dissent them. Taqi al-din al-Subqi collected his fatwas under the title of Fatâwâ Abu Hurairah. Unfortunately this book is not extant today. In this study, we give fatwas of Abu Hurairah which we found.

In the light of this information, it is possible to make the following determinations about whether Abu Hurairah was faqih or not:

i. Abu Hurairah was an authority in hadiths with determination of the companions.

ii. His association with the Prophet (pbuh), his continuity for His conversations and his witnessing the sunnah made Abu Hurairah have a deep tact in religious issues.

iii. There are fatwas belong to him that corresponded with fatwas of leading companions like Omar b. al-Khattab, 'Ali, Ibn Omar, Zayd b. Thabit, Ibn 'Abbas who were well-known for having a deep understanding in fiqh or dissented them.

iv. The argument that the founder imams of Hanafi school did not accept some transmissons of Abu Hurairah due to not being a faqih is not accepted by all of Hanafi scholars. Thus, there is not a uniformity in the school about this issue.

v. His responses and fatwas for issues related to fiqh support that he was a faqih.

vi. It should be noted that he can not be compared with the leading faqihs of the companions such Omar b. al-Khattab, 'Ali, Ibn Omar, Aisah and Ibn Mas' $\bar{u} d$ in terms of competence in fiqh.

\section{Keywords}

Islamic Law, Abu Hurairah, Hanafĩ Madhhab, Fiqh al-Rāwī, Musarrah Hadith

\section{Ebû Hüreyre'nin Fakihliği Meselesi}

\section{Öz}

Ebû Hüreyre ismine İslâmî ilimlerin pek çok alanında rastlamak mümkündür.Hz. Peygamber'in (s.a.v) vefâtından yaklaşık üç yıl önce Medîne'ye gelmiş olmasına rağmen sahâbenin en fazla hadis nakledeni olması, zaman zaman yadırganmış ve çeşitli ithamlara sebep olmuştur. Ebû Hüreyre bazı sahâbîler tarafından hadis nakli konusunda yöneltilen eleştirilere, kendisinin $\mathrm{Hz}$. Peygamber'in yanından ayrılmayıp hadis öğrenme konusunda gösterdiği azim ve gayrete vurgu yaparak "Muhacirler çarşı pazarda ticaretle; Ensar bağ bahçede, mal mülk geçim derdiyle uğraşırken ben karın tokluğuna Hz. Peygamber'in yanından ayrılmıyordum” diyerek cevap vermiştir. Ayrıca Hz. Peygamber' in onun bu azim ve gayretini takdir ettiğine ve hafızasının güçlenmesi için dua ettiğine dair rivayetler kaynaklarda yer almaktadır. Bunun yanı sıra Abdullahb. Ömer, Zeyd b. Sâbit, Talha b. Ubeydullah gibi sahâbîler de Ebû Hüreyre'nin hadis konusunda yetkin ve otorite olduğunu ifade etmişlerdir. 
Ebû Hüreyre ile ilgili tartışmalardan bir diğeri ise onun fakih olup olmadığı meselesidir. Bu konu, bazı rivayetleri bağlamında özellikle Hanefî hukukçular tarafından gündeme getirilmiştir. İsa b. Ebân gibi bazı Hanefî hukukçular Ebû Hanîfe, Ebû Yûsuf, İmam Züfer, İmam Muhammed gibi mezhebin kurucu imamlarının kıyasa/genel kurala aykırı olan musarrât ve ariyye gibi hadislerle amel etmeme gerekçelerini rivayetleri nakleden Ebû Hüreyre'nin fakih olmamasıyla açıklamışlar ve fikhu'r-râvi şartını kıyasa ya da genel kurala muhalif olanâhâd rivayetlerle amel edilmesi için olmazsa olmaz bir şart olarak ileriye sürmüşlerdir. Bu görüşü benimseyen hukukçular konunun gündeme geldiğiyerlerde genellikle musarrat/muhaffele hadisini örnek vermekte ve Ebû Hüreyre fakih olmadığı için bu rivayetle amel edilmediğini iddia etmektedirler. Ancak Hanefî mezhebi içerisinde başta Ebü'l-Hasan el-Kerhî olmak üzere pek çok hukukçu bu iddiayı kabul etmemişler ve fikhu'r-râvi şartını kabul etmemişlerdir. Nitekim kurucu imamlardan da bu konuda herhangi bir görüş nakledilmemiştir. Aksine kıyasa ve genel kurala aykırı olan bu tür rivayetlerle amel ettikleri rivayet edilmiştir. Hatta kurucu imamlar, muhayyerliğin süresini belirleyen Ebû Hüreyre'nin naklettiği musarrat hadisinin ilk kısmılla amel etmişlerdir. Bu konuda dikkat çeken bir diğer husus ise, bu hadisi Hanefî mezhebinin fikıh anlayışının oluşumunda ve şekillenmesinde çok önemli bir yere sahip olan İbn Mes'ûd da rivayet etmiştir. Ancak rivayetin İbn Mes'ûd tarikine, Hanefî fikıh kaynaklarında ya "belağana" şeklinde râvi ismi zikredilmeksizin ya da "ruviye", "yürvâ" şeklinde meçhul sîgayla yer verilmiş ve İbn Mes'ud'dan hiç bahsedilmemiştir. Ayrıca musarrât hadisinin İbn Ömer ve Enes b. Mâlik tariklerine de Hanefî kaynaklarda yer verilmemiştir. Hanefî mezhebi içerisinde Ebû Hüreyre'nin sahâbenin fakihlerinden birisi olduğunu savunan ve fakih olmadığı yönündeki iddialara karşı çıkan hukukçular da vardır. Bu iki yaklaşım göz önünde bulundurulduğunda fikhu'r-râvî şartının kabulü ya da reddi konusunda Hanefî mezhebi içerisinde bir yeknesaklığın, homojenliğin olduğunu söylemek mümkün değildir.

Ebû Hüreyre'den bahseden gerek tarih gerekse biyografi/bibliyografik kaynaklar onu fakih ve müctehid olarak nitelemektedir. Ayrıca Hz. Ömer tarafından Ebû Hüreyre'nin Bahreyn'e kaza ve yargı işleriyle ilgilenmek üzere gönderilmesi ve daha sonra buraya vali tayin edilmesi onun sahip olduğu fikıh birikimine güvenildiğinin bir göstergesidir. Bunlara ek olarak Ebû Hüreyre'nin sahâbenin önde gelen fakihleriyle birlikte vermiş olduğu onlara muhâlif ya da muvâfik fetva örnekleri de bulunmaktadır. Nitekim Takiyyüddîn es-Sübkî, Ebû Hüreyre'nin fetvalarını Fetâvâ Ebî Hüreyre ismiyle bir cüz halinde toplamışır. Ne yazık ki bu eser günümüze ulaşmamıştır. Biz de, Ebû Hüreyre'nin fetvalarından tespit edebildiklerimize çalışmamızda yer verdik.

Bu bilgilerin ışığında Ebû Hüreyre'nin fakihliği konusunda şu tespitleri yapmak mümkündür: i. Ebû Hüreyre, sahâbenin de tespitiyle hadis konusunda otorite bir şahsiyettir.

ii. Hz. Peygamber (s.a.v.) ile olan birlikteliği, sohbetlerine devamlılığı ve her yönüyle amelî (yaşayan) sünnete şahit oluşu Ebû Hüreyre'nin din konusunda ince anlayış, derin kavrayış (tefakkuh) sahibi olmasına imkân sağlamıştır.

iii. Örneklerde de görüldügüü üzere Ebû Hüreyre'nin Hz. Ömer, Hz. Ali, İbn Ömer, Zeyd b. Sabit, İbn Abbas gibi sahâbeden fikhıla maruf olan isimlerin fetvâlarına muvâfık ya da muhâlif fetvalar verdiği kaynaklarda sabittir.

iv. Bazı Hanefî hukukçuların ileri sürdüğü kurucu imamlarının Ebû Hüreyre'nin bazı rivayetleriyle fakih olmadığı gerekçesiyle amel etmedikleri şeklindeki iddia, bütün Hanefî hukukçular tarafından kabul edilen bir yaklaşım değildir. Dolayısıyla bu konuda mezhep içerisinde bir yeknesaklık yoktur.

v. Ebû Hüreyre'nin fikhî meselelere getirdiği çözümler ve verdiği fetvalar onun fakih olduğu yönündeki tezi desteklemektedir. 
vi. Bu sonuçların yanı sıra Ebû Hüreyre'nin fikıh nosyonu ve donanımı açısından Hz. Ömer, Hz. Ali, İbn Mes'ûd, Hz. Âişe, İbn Abbas (r.a.) gibi sahâbenin önde gelen fakihleriyle kuyaslanamayacağı da bir gerçektir.

\section{Anahtar Kelimeler}

İslam Hukuku, Ebû Hüreyre, Hanefî Mezhebi, Fikhu'r-Râvi, Musarrât Hadisi

\section{Giriş}

İslâmî ilimler incelendiğinde hemen hemen her ilim dalında Ebû Hüreyre (öl. 58/678) ismine rastlamak mümkündür. Kaynaklarda risalet döneminin sonlarına doğru Müslüman olup Medine'ye geldiği kaydı bulunmasına rağmen tekrarlarla birlikte 5374 hadisle en fazla nakilde bulunan (müksirûn) ${ }^{1}$ sahâbîlerin başında gelmesi, Ebû Hüreyre'yi (r.a.) özel ilgi konusu yapmış ve tartışmaların da merkezine oturtmuştur. Özellikle Hz. Peygamber'le (s.a.v.) birlikteliği kısa olmasına rağmen bu kadar hadis rivayet etmiş olması kimilerince yadırganmış, bu sebeple çeşitli iddia ve ithamlara maruz kalmıştır. ${ }^{2}$

Kaynaklarda Ebû Hüreyre'nin hicretin 7. (628) yllında Müslüman olup Medîne'ye geldiği ${ }^{3}$ ve Hz. Peygamber vefât edinceye kadar Mescid-i Nebevînnin bitişiğinde kimsesiz ve fakir sahâbîlere tahsis edilmiş Suffe'de kalarak O'ndan ilim öğrenmeye devam ettiği kaydedilmektedir. ${ }^{4}$ Onun, Hz. Peygamber'in yanından ayrılmayı hadis öğrenme konusunda gösterdiği azim ve gayret ${ }^{5}$ pek çok hadis rivayet etmesine ve diğer sahâbîlerin işitmedikleri bazı rivayetleri duymasına ve nakletmesine imkân tanımıştır. Ayrıca Hz. Peygamber'in Ebû Hüreyre'nin hafizasının kuvvetlenmesi için dua ettiğine dair rivayetler de hadis kaynaklarında mevcuttur. ${ }^{6}$ Ayrıca Abdullah b. Ömer, Zeyd b. Sâbit, Talha b. Ubeydullah gibi sahâbîler tarafindan Ebû Hüreyre'nin hadis konusundaki yetkinliği ve otorite oluşu bizzat tespit edilmiştir. ${ }^{7}$ Çok sayıda hadis rivayetinden dolay1 kendisine yöneltilen tenkitlere "Muhacirler çarşı pazarda ticaretle; Ensar bağ bahçede, mal

1 Ebû Hüreyre'nin mükerrerleriyle birlikte 5374 rivayeti bulmaktadır. Bk. M. Yaşar Kandemir, “Ebû Hüreyre", Türkiye Diyanet Vakfi İslam Ansiklopedisi (İstanbul: TDV Yayınları, 1994), 10/162; Cemal Ağırman, "Müksirûn", Türkiye Diyanet Vakfi İslam Ansiklopedisi (İstanbul: TDV Yayınları, 2006), $31 / 534$.

2 Mesela Muhammed Ebû Reyye tarafından kaleme alınan Şeyhu'l-madîre Ebû Hureyre (Kâhire: Dâru'lMaârif, ts.) ve Edvâ' ale's-sünneti'l-Muhammediyye ev difấ 'ani'l-hadîs (Beyrut: Müessesetü'l-Âlemî, 1957) isimli eserler buna örnek verilebilir. Çok hadis rivayet etmesi sebebiyle kendisine yöneltilen tenkitler için bk. Kandemir, "Ebû Hüreyre", 10/164-166.

3 Şemseddin Muhammed b. Ahmed b. Osman ez-Zehebî, Tezkiratü'l-huffâz (Haydârabâd: Matbaatü Meclisi Dâirati'l-Maârifi'n-Nizamiyye, 1333), 1/32.

4 Kandemir, "Ebû Hüreyre", 10/160.

5 Ebû Hüreyre'nin hadis öğrenme konusundaki azim ve gayretinin bizzat Hz. Peygamber tarafından tespit ve takdir edildiğini gösteren hadisler için bk. Buhârî, "ilim, 33; "Rikâk", 51; Nesâî, "illim”, 3.

6 Ahmed b. Hanbel, Müsned, 12/219; Buhârî, "ilim, 42; "Menâkıb", 28; İ'tisâm", 22; Müslim, "Fedâilu's-sahâbe", 35; Tirmizî, "Menâkıb", 47.

7 Ebü'l-Fazl Şihâbüddîn Ahmed b. Alîb. Muhammed İbn Hacer el-Askalânî, el-İsâbe fi temyizi's-sahâbe, thk. Adil Ahmed Abdülmevcud-Ali Muhammed Muavvaz (Beyrut: Dâru'l-Kütübi'l-İlmiyye, 1995), 7/357; Kandemir, "Ebû Hüreyre", 10/164. 
mülk geçim derdiyle uğraşırken ben karın tokluğuna Hz. Peygamber'in yanından ayrılmıyordum"8 diyerek cevap vermiştir.

Sahâbenin hadis rivâyeti konusunda en önde geleni olmasına rağmen Ebû Hüreyre'nin fakih olup olmadığı meselesi ulema arasında tartışılmıştır. Konunun bu kadar ilgi uyandırmasının sebebi, fakih olmadığı için bazı rivayetlerinin kıyasa/genel kurala aykırı olduğu gerekçesiyle kimi Hanefî hukukçular tarafından terk edilip, k1yasın tercih edilmesidir. Bu çalışmada konuyla ilgili literatürdeki tartışmalar göz önünde bulundurularak Ebû Hüreyre'nin fakih olup olmadığı meselesi ele alınmaya çalışılacaktır. Bu noktada literatür taraması yapılarak Ebû Hüreyre'ye ait fetva örneklerinin olup olmadığı tespit edilmeye gayret edilecektir.

Ebû Hüreyre'nin fakihliği konusunda iki yaklaşımın öne çıtı̆̆ı söylenebilir: Bunlardan birisi Ebû Hüreyre'nin gerek Hz. Peygamber hayattayken gerekse sonrasında sahâbe içerisinde fetva verdiği, farklı zamanlarda vâlilik ve kadılık görevleri dolayısıyla fakih ve müctehid olduğunu savunan görüş; diğeri ise fikhıla maruf olmadığını, bu yüzden kıyasla çelişmesi durumunda mütevatir ve meşhur seviyesine ulaşmayan rivayetleriyle amel edilmeyeceği ve kıyasın tercih edileceğini savunan görüştür. Şimdi iki tarafın görüşlerini ve delillerini ele alalım.

\section{Ebû Hüreyre'nin Fakih Olmadığını Savunanlar ve Gerekçeleri}

Hanefî mezhebinde Ebû Hüreyre'nin bazı rivayetleriyle amel edilmemiştir. Bu konuda en fazla gündeme getirilen rivayetlerin başında musarrât ${ }^{9}$ ve ariyye ${ }^{10}$ hadisleri gelmektedir. Hanefî fakihlerinden İsa b. Ebân (öl. 221/836), mezhebin kurucu imamları Ebû Hanîfe, Ebû Yûsuf, İmam Züfer ve İmam Muhammed'in bu tür rivayetlerle amel etmeme gerekçesini Ebû Hüreyre'nin fakih olmamasılla izah etmiş ve meseleyi "fikhu'rrâvi" şartı ile temellendirmiştir. ${ }^{11}$ Kendisinden sonra gelen Cessâs (öl. 370/981) ve Debûsî (öl. 430/1039) gibi pek çok Hanefî fakih ve usûlcü de benzer bir yaklaşım sergileyerek Ebû Hüreyre'nin fakih olmadığını iddia etmişlerdir. Bu bağlamda Cessâs, rivayeti kıyasla uyumlu ise kabul edilir; değilse kabul edilmez, diyerek İsâ b. Ebân'ın konuyla ilgili görüşünü aktarmak suretiyle onun görüşünü benimsediğini göstermiştir/ortaya

8 Ahmed b. Hanbel, Müsned, 12/219; Buhârî, "Büyû", 1; "Müzâraa”, 17; “İtisâm”, 22; Müslim, "Fedâilu's-sahâbe", 35.

9 Buhârî, "Büyû", 64,65; Müslim, "Büyû", 11, 24, 25, 28; Ebû Dâvud, "Büyûu”, 46.

10 Ahmed b. Hanbel, Müsned, 12/175; Nesâî, "Büyû", 35.

11 Ebû Bekir Ahmed b. Ali er-Râzî el-Cessâs, el-Fusûl fi'l-usûl, thk. Uceyl Câsim Neşemî (İstanbul: Mektebetü'l-İrşâd, 1994), 3/129; Ebû Zeyd Ubeydullah b. Muhammed ed-Debûsî, Takvîmü'l-edille fî usûli'l-fikh, thk. Halil Muhyiddîn el-Meys (Beyrut: Dâru'l-Kütübi'l-İlmiyye, 2007), 182; Alâüddin Abdülazîz b. Ahmed el-Buhârî, Keşfü'l-esrâr an Usûli Fahri'l-İslam el-Pezdevî (Beyrut: el-Mektebetü'l-Asriyye, 2012), 2/707; Zeynüddin b. İbrâhim İbn Nüceym, Fethu'l-ğaffâr bi şerhi'l-Menâr (Mısır: Şerikatü Mektebetü ve Matbaatü Mustafa, 1936), 2/90; Abdülkadir b. Muhammed Kureşî, el-Cevâhirü'l-mudiyye fí tabakâti'l-Hanefiyye, thk. Abdülfettah Muhammed el-Hulv (Kâhire: Dâru'l-Hicr, 1993), 4/538539; Murteza Bedir, Fıkıh, Mezhep ve Sünnet (İstanbul: Ensar Neşriyat, 2004), 101-104; Chamntı Ts1lıgkır, "Hanefîlere Göre Haberin Kıyasa Aykırı Olması Durumunda Râvinin Fakih Olma Şartı", Sakarya Üniversitesi İlahiyat Fakültesi Dergisi, 21/1 (2010), 71-72. 
koymuştur. ${ }^{12}$ Benzer bir yaklaşım sergileyen Debûsî de rivayetin kıyasla çelişmesi durumunda râvi rey ve fikı ehlinden değilse, kıyas sebebiyle haberinin reddedileceğini belirtmiştir. ${ }^{13}$

Özellikle İsa b. Ebân tarafından ileri sürülen Ebû Hüreyre'nin fakih olmadığı tezi, tartışmaları da beraberinde getirmiş, mezhep içerisinden başta Ebü'l-Hasan el-Kerhî (öl. 340/952) olmak üzere bu teze karşı çıkanlar olmuştur. ${ }^{14}$

Ebû Hüreyre'nin fakih olmadığını savunanlar, görüşlerini temelde iki gerekçeye dayandırmışlardır. Bunlardan birisi Ebû Hüreyre'nin bazı rivayetlerinin sahâbe tarafından çeşitli gerekçelerle reddedilmesi; ${ }^{15}$ diğeri de rivayetlerin büyük bir kısmını mana yoluyla nakletmiş olmasıdır. Bu, Ebû Hüreyre'nin “murad-ı Neb̂̂”yi tam olarak kavrayamadığının göstergesidir. Nitekim özellikle muâmelâta dair bazı rivayetleri eksik ya da hatalı nakletmiş olmasında “murad-ı Neb̂̂”yi tam olarak anlayamadı̆̆ı açıkça görülmektedir. ${ }^{16}$

\subsection{Ebû Hüreyre'nin Bazı Rivayetlerinin Akla ve Kıyasa Aykırı Olması}

Ebû Hüreyre'nin bazı rivayetleri, Hz. Ömer, Hz. Ali, Hz. Âişe ve İbn Abbas (r.a.) gibi fikhıyla maruf sahâbîler tarafından kıyasa ya da şer'î esaslara aykırı olduğu gerekçesiyle tenkide uğramıştır. Ebû Hüreyre tarafından nakledilen ateşin dokunduğu şeylerden dolayı abdestin gerekli olduğu, ${ }^{17}$ tek terlikle yürüme yasağı, ${ }^{18}$ veledi zinanın üç kişinin en şerlisi olduğuna ${ }^{19}$ dair rivayetleri burada zikredilebilir. ${ }^{20}$

Ancak bu tür eleştirilere uğrayan sadece Ebû Hüreyre olmamıştır. Benzer eleştiriler ilmi ve verdiği fetvalarıyla meşhur olan, fikıh konusunda otorite kabul edilen "abâdile"den Abdullah b. Ömer'in rivayetlerine de yapılmıştır. Mesela Abdullah b. Ömer'in nakletmiş olduğu "Şüphesiz ki ölü, yakınlarının arkasından ağlamasından dolayı azap görür" ${ }^{21}$ hadisi, Hz. Âişe tarafından "Hiçbir günahkâr başkasının günah yükünü yüklen

\footnotetext{
Cessâs, el-Fusûl fi'l-usûl, 3/129; Debûsî, Takvîmü'l-edille, 180; Abdulazîz el-Buhârî, Keş̧ü'l-esrâr, 2/705.

Debûsî, Takvîmül-edille, 180.

14 Abdulazîz el-Buhârî, Keşfü'l-esrâr, 2/707; Kureşî, el-Cevâhirü'l-mudıyye, 4/538-539; Tsılıgkır, "Hanefîlere Göre Haberin Kıyasa Aykırı Olması Durumunda Râvinin Fakih Olma Şartı”, 72; Rıdvan Yarba, “Tartışmalı Bazı Hadisleri ve Fetvaları Bağlamında Ebû Hüreyre'nin Fakihliği Meselesi”, İslam Medeniyetinin Kurucu Nesli Sahâbe -Sahâbe ve Dirâyet İlimleri- III, ed. Abdullah Aydınlı v.dğr. (İstanbul: Ensar Neşriyat, 2018), 155.

15 Cessâs, el-Fusûl fi'l-usûl, 3/131; Debûsî, Takvîmü'l-edille, 181; Şemsüleimme Ebû Sehl Ebû Bekir Muhammed b. Ahmed es-Serahsî, el-Usûl, thk. Ebu'l-Vefâ el-Efgânî (Beyrut: Dâru'l-Kütübi'l-i̇lmiyye, 1973), 1/340-341; Abdulazîz el-Buhârî, Keşfü'l-esrâr, 2/707.

16 Debûsî, Takvîmül-edille, 181; Serahsî, el-Usûl, 1/341-342; Abdulazîz el-Buhârî, Keşfü'l-esrâr, 2/702, 706; Ubeydullah b. Mes'ud b. Mahmûd el-Buhârî el-Mahbûbî es-Sadrüşşerîa, et-Tavdîh ale't-Tenkîh, thk. Saîd el-Ebraş (Dimaşk: Mektebetü Merzûk, 2006), 267-268.

17 Müslim, "Tahâret”, 90; İbn Mâce, "Îman”, 2; Ebû Dâvud, "Tahâret”, 76; Tirmizî, "Tahâret”, 58.

18 Buhârî, "Libâs”, 40; Müslim, "Libâs”, 67-69.

19 Ebû Dâvud, "Itk", 12.

${ }^{20} \mathrm{Bu}$ rivayetlere yöneltilen eleştiriler için bk. Cessâs, el-Fusûl fi'l-usûl, 3/127-129; Tsılıgkır, "Hanefîlere Göre Haberin Kıyasa Aykırı Olması Durumunda Râvinin Fakih Olma Şartı”, 75.

21 Buhârî, "Cenâiz", 33, 34; Müslim, "Cenâiz", 16, 18, 19, 22-24.
} 
mez. İnsana ancak çalıştığının karşılı̆̆ı vardır"22 ayetine ters düştüğü gerekçesiyle reddedilmiştir. ${ }^{23}$ Aynı şekilde Hz. Ömer, Zeyd b. Sabit, Abdullah b. Abbas gibi fikhıla maruf diğer bazı sahâbîlere de benzer tenkitler yapılmıştır. Bu tenkitlerin sayısı hiç de az değildir. ${ }^{24}$ Görüldüğü üzere sahâbenin yönelttiği bu eleştiriler sadece Ebû Hüreyre'ye özgü bir durum olmayıp diğer sahâbîler de bir şekilde eleştirilmiştir. ${ }^{25}$ Dolayısıyla bu eleştirilerin yöneltilmesinde ana etken onun fakih olup olmaması değildir. Çünkü pek çok kaynakta Ebû Hüreyre'nin, sahâbenin fakihleri ve fetva verenleri arasında zikredildiği görülmektedir.

\subsection{Ebû Hüreyre'nin Bazı Rivayetlerinin Şer'î Esaslara Aykırı Olması}

Hanefî mezhebinin kurucu imamları İslam'ın ortaya koyduğu tazmin esaslarıyla bağdaşmadığı için musarrât hadisiyle amel etmemişlerdir. ${ }^{26}$ Ancak bu rivayetle amel etmeme gerekçeleri arasında Ebû Hüreyre'nin fakih olmayışı hususu yer almamıştır. Bununla birlikte daha sonra gelen Hanefî fakih ve usulcüleri kurucu imamların görüşlerini temellendirirken haber-i vâhidin kıyasa/genel kurala aykırı olması halinde rivayetin tercih edilebilmesi için râvinin fakih olmasını şart koşmuşlardır. Bu şart ilk olarak İsa b. Ebân (öl. 221/836) tarafından ileri sürülmüş; Cessâs, Debûsî ve müteahhir usulcülerin bir kısmı tarafından da benimsenmiştir. Bu görüş sahipleri kurucu imamların musarrât ve arâya ${ }^{27}$ hadisleriyle amel etmemelerini de Ebû Hüreyre'nin fakih olmayışıyla açıklamışlardır. ${ }^{28}$

Mezhep içerisinde râvinin fakih olması şartını ileri süren usulcülerin yanı sıra Ebü'l-Hasen el-Kerhî (öl.340/952) gibi bu rivayetlerle amel edilmemesinin râvinin fakih olmamasından değil başka sebeplerden kaynaklandığını savunan fakihler de bulunmaktadır. Kerhî ve ona tâbi olanlar, haberin kıyasa takdimi için râvinin fakih olmasını şart koşmamışlardır. Bilakis adalet ve zabt sahibi kabul edilen her râvinin rivayetinin Kitab'a ve meşhur sünnete muhalif olmadığı sürece kıyasa tercih edileceğini belirtmişlerdir. Pezdevî, alimlerin çoğunun Kerhînin görüşüne meylettiğini söylemiştir. ${ }^{29}$

22 Necm, 53/38-39.

23 Ebû İshak İbrâhim b. Musa b. Muhammed el-Gırnâtî Şâtıbî, el-Muvâfakât (Kâhire: Dâru'l-Hadis, 2006), 3/15; Ebû Abdullah Bedreddin Muhammed b. Bahadır b. Abdullah Zerkeşî, Hz. Âişe'nin Sahabeye Yönelttiği Eleştiriler, çev. Bünyamin Erul (Ankara: Kitabiyât, 2008), 72-73.

24 Geniş bilgi için bk. Zerkeşî, Hz. Âişe'nin Sahabeye Yönelttiği Eleştiriler, 67-163.

25 Kandemir, "Ebû Hüreyre", 10/164.

26 Buhârî, "Büyû", 64,65; Müslim, "Büyû", 11, 24, 25, 28; Ebû Dâvud, "Büyûu”, 46.

27 Ahmed b. Hanbel, Müsned, 12/175; Nesâ̂, "Büyû", 35.

28 Abdulazîz el-Buhârî, Keşfü'l-esrâr, 2/707; Ebû Muhammed Bedreddin Mahmûd b. Ahmed b. Musa el-Aynî, Umdetü'l-kâri şerhu Şahîhil-Buhârî (Beyrut: Dâru'l-Kütübi'l-İlmiyye, 2001), 12/339; İbn Nüceym, Fethü'lğaffâr, 2/90; Kureşî, el-Cevâhirü'l-mudiyye, 4/538-539; Salim Ögüt, İslam Hukuk Metodolojisinde Haber-i Vâhid’in Kaynak Değeri (İstanbul: Ocak Yayınc1lık, 2003), 53-54; Şükrü Özen, “İsa b. Ebân”, Türkiye Diyanet Vakfi İslam Ansiklopedisi (İstanbul: TDV Yayınları, 2000), 22/481; Metin Yiğit, Ebû Hanîfe’nin Usûl Anlayışında Sünnet (İstanbul: İz Yayıncılık, 2009), 241; Yarba, “Tartışmalı Bazı Hadisleri ve Fetvaları Bağlamında Ebû Hüreyre'nin Fakihliği Meselesi”, 153.

29 Abdulazîz el-Buhârî, Keşfü'l-esrâr, 2/707; İbn Nüceym, Fethu'l-ğaffâr, 2/90; Kureşî, el-Cevâhirü'l-mudıyye, 4/538539; Tsıllgkır, "Hanefillere Göre Haberin Kıyasa Aykırı Olması Durumunda Râvinin Fakih Olma Şartı", 72; Yarba, “Tartışmalı Bazı Hadisleri ve Fetvaları Bağlamında Ebû Hüreyre’nin Fakihliği Meselesi”, 153. 
Hanefî fukahasının ileriye sürdüğü her iki yaklaşım da göz önünde bulundurulduğunda fikhu'r-râvî şartının kabulü ya da reddi konusunda mezhep içerisinde bir yeknesaklığın, homojenliğin olduğunu söylemek mümkün gözükmemektedir. Ayrıca bu iki yaklaşımdan birisini tercih eden hukukçular mezhep içerisindeki yaygın görüşün kendi görüşleri olduğunu söylemekte ve bunu çeşitli argümanlarla desteklemeye çalıştıkları görülmektedir.

Mezhebin kurucu imamlarının meseleye yaklaşımlarına bakıldı̆̆ında, onların böyle bir şart ileri sürmeleri bir yana sahih olan haber-i vahidin kıyasa tercih edileceğine dair açık beyanlarının olduğu görülmektedir. Nitekim Ebû Hanîfe'nin, "Bizim kıyası nassa öncelediğimizi söyleyen yalan söylüyor ve bize iftira ediyor. Nass bulunduktan sonra kıyasa ihtiyaç mı kalır?" 30 sözleri, bu konudaki tavrını açıcça ortaya koymaktadır. Yine Ebû Hüreyre'nin naklettiği unutarak yiyip içmenin orucu bozmayacağına dair rivayet, kıyasa/genel kurala aykırı olmasına rağmen mezhep içerisinde makbul sayılmiş ve kendisiyle amel edilmiştir. Hatta Ebû Hanîfe bu hususla ilgili olarak "Eğer rivayet olmasaydı kıyasa göre hüküm verirdim" dediği de kaynaklarda sabittir. ${ }^{31}$ Zaten mezhebin ilk dönem kaynakları incelendiğinde de Ebû Hanîfe'nin Ebû Hüreyre'nin rivayetlerine yönelik olumsuz bir tavır içerisinde olmadı̆̆ı da görülmektedir. ${ }^{32}$

Ebû Hanîfe'nin tavrına benzer bir yaklaşımın, İsa b. Ebân'ın hocası olan İmam Muhammed tarafından da sergilendiği görülmektedir. O, Mâlikî mezhebine karşı mezhep müdafaası mahiyetinde kaleme aldığı eseri el-Hücce alâ ehl-i Medîne'de Mâlikîlerin, namazda kahkahanın abdesti değil sadece namazı bozduğu şeklindeki görüşlerine karşılık, "Şayet hadisler olmasaydı, kıyas Medîne ehlinin dediği gibi olurdu. Lakin hadisle birlikte kıyas olmaz. Mutlaka hadise tabi olunması gerekir" demiştir. ${ }^{33}$ Yine İmam Muhammed'in naklettiğine göre Ebû Hanîfe, râvisi fakih olmayan birçok rivayetle istidlalde bulunmuştur. Onlardan birisi hayzın süresinin takdiri meselesidir ki, onu da Enes b. Mâlik nakletmiştir. Ebû Hüreyre ise ilim bakımında Enes'ten daha üstündür. ${ }^{34}$ Ayrıca nifasın üst limitinin kırk gün olacağı görüşünü benimseyen Hanefîlerin dayanağını oluşturan rivayeti nakledenlerden birisi de Ebû Hüreyre'dir. ${ }^{35}$

30 Abdülvehhab eş-Şa'rânî, Kitâbü'l-Mîzân, thk. Abdurrahman Umeyre (Beyrut: Âlemü'l-Kütüb, 1989), 1/224; Ebü'l-Hasan Nureddin Ali b. Sultan Muhammed Ali el-Kârî, Şerhu Müsnedi Ebî Hanîfe, thk. Halil Muhyiddin el-Meys (Beyrut: Dâru'l-Kütübi'l-İlmiyye, 1985), 4; Muhammed Ebû Zehre, Ebû Hanîfe: Hayâtuhu ve asruhu-ârâuhu ve fikhuhu (Kâhire: Dârü'l-Fikri'l-Arabî, ts.), 303.

31 Abdülazîz el-Buhârî, Keşfü'l-esrâr, 2/708; i̇bn Nüceym, Fethu'l-ğaffâr, 2/91; Şah Veliyyullâh ed-Dihlevî, el-İnsâf fí beyâni esbâbi'l-ihtilâf (Beyrut: Dâru'n-Nefâis, 1986), 91-92; İsmail Hakkı Ünal, İmam Ebû Hanîfe'nin Hadis Anlayışı ve Hanefì Mezhebinin Hadis Metodu (Ankara: Diyanet İşleri Başkanlığı Yayınları, 2012), 184.

32 Yiğit, Ebû Hanîfe'nin Usûl Anlayışında Sünnet, 232.

33 Muhammed b. Hasan eş-Şeybânî, Kitabu'l-Hucce ale ehli Medîne (Beyrut: Âlemü'l-Kütüb, 1403), 1/204; Ünal, İmam Ebû Hanîfe'nin Hadis Anlayılsıl, 185.

34 Abdülazîz el-Buhârî, Keşǘ'l-esrâr, 2/708.

35 Alâüddîn Ebû Bekir b. Mes'ûd Kâsânî, Bedâi 'u's-sanâi' fit tertîbi'ş-șerâi' (Beyrut: Dâru'l-Kütübi'l-Arabî, 1982), $1 / 41$. 
Hanefî fakihlerinden Abdulaziz el-Buhârî (öl. 730/1330) de "Ebû Hanîfe 'Allah ve Resûlünden bize gelen her şey başımı gözümüz üstünedir' demiştir. Seleften (kurucu imamlardan) hiç kimseden râvinin fakih olması gerektiği şartı nakledilmemiştir. Bu görüşsonradan ortaya çıkmıştır (müstehdestir)"36 sözleriyle bu şartın daha sonra ortaya çıktığına işaret etmektedir. Nitekim mezhebin kurucu imamları, özellikle Ebû Yûsuf ve İmam Muhammed pek çok fikhî meselede Ebû Hanîfe'nin görüşlerini savunurken Ebû Hüreyre'nin rivayetlerini delil olarak kullanmışlardır. Bu yaklaşım Tahâvî ve Mâturîdî gibi sonraki dönem Hanefî fakihleri tarafından da sürdürülmüştür. ${ }^{37}$

İlk dönem Hanefî usulcülerinin rivayetin kabulü için ravinin fakih olma şartını ileri sürmedikleri ancak daha sonra mezhep içerisinden bazı usulcülerin buna muhalif görüşlerinin mezhebin görüşüymüş gibi algılanmaya başladığı görülmektedir. Bu konuda mezhep içerisinde homojen bir yaklaşımdan bahsedilemez.

Fıkhu'r-râvi tartışması bağlamında gündeme getirilen sembol örneklerden biri olan ve Ebû Hüreyre tarafından nakledilen musarrât/muhaffele hadisini burada rivayetin farklı tariklerini vererek incelemenin yerinde olacağını düşünüyoruz.

\subsubsection{Ebû Hüreyre'nin Tenkide Konu Olan Musarrât/Muhaffele Rivayeti}

Hanefî mezhebinde akla, kıyasa ve şer î esaslara aykırı olduğu, râvisinin fakih olmadığı gibi çeşitli gerekçeler ileri sürülerek musarrât/muhaffele hadisiyle amel edilmediği bir gerçektir. Bu gerekçelerden birisi de rivayeti nakleden Ebû Hüreyre'nin fakih olmamasıdır. Ancak bu rivayetin -tespit edebildiğimiz kadarıyla- bilinen Ebû Hüreyre rivayeti dişında tartışmalarda hiç gündeme getirilmeyen üç farklı tariki daha bulunmaktadır. Bu hadis, sahâbeden fikhıla meşhur/maruf olan ve fakih oldukları konusunda ulemanın hemfikir olduğu "abâdile"den Abdullah b. Mes $^{\text {'ûd }}{ }^{38}$ ve Abdullah b. Ömer ${ }^{39}$ ile Enes b. Mâlik'ten de rivayet edilmiştir. ${ }^{40}$ Ancak ilginçtir ki, musarrât hadisi ekseninde cereyan eden tartışmaların söz konusu edildiği Hanefî literatüründe rivayetin Ebû Hüreyre dişındaki tariklerine -neredeysehiç yer verilmemiş olması dikkat çekicidir. Hanefî kaynaklarda özellikle İbn Mes'ûd ve İbn Ömer tarikleri söz konusu olduğunda râvilerinin zikredilmeyip (بنغا عن رسول

36 Abdulazîz el-Buhârî, Keşfu'l-esrâr, 2/708. Ayrıca bk. Yiğit, Ebû Hanîfe' nin Usûl Anlayışında Sünnet, 234.

37 Yiğit, Ebû Hanîfe'nin Usûl Anlayışında Sünnet, 234.

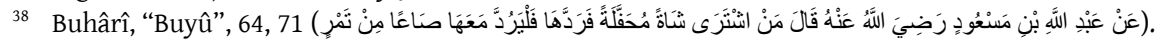
İbn Mes'ûd'un rivayetinde İbn Ömer ve Ebû Hüreyre rivayetlerinden farklı olarak müşterinin üç

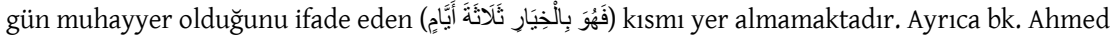
b. Hanbel, Müsned, thk. Şuayb el-Arnaût v. dğr. (Beyrut: Müessesetü’r-Risâle, 1999), 7/171; İbn Ebî Şeybe, el-Musannef, 6/596; Abdürrezzâk b. Hemmâm es-San'ânî, el-Musannef, 8/198.

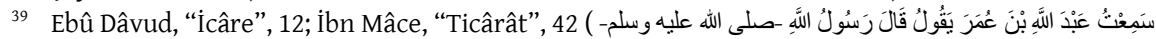

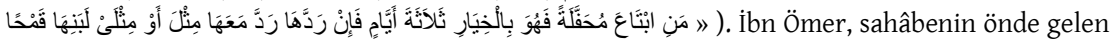
fakihlerinden birisidir. Sahâbeden en çok fetva veren yedi kişiden birisidir. Bk. Muhammed Ravvâs el-Kal'âcî, Mevsû́atü fikhi Abdillâh b. Ömer (Beyrut: Dâru'n-Nefâis, 1986), 25-26; M. Yaşar Kandemir, “Abdullah b. Ömer b. el-Hattâb”, Türkiye Diyanet Vakfi İslam Ansiklopedisi (İstanbul: TDV Yayınları, 1988), 1/127.

40 Beyhakî, es-Sünenü'l-kübrâ, 5/321. 


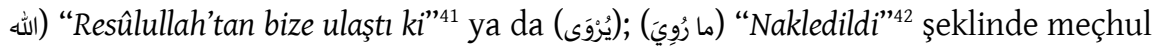
sîgayla yer verilmesi dikkati câlib bir durumdur.

Özellikle İbn Mes'ûd'un fikhî görüşlerinin Hanefî mezhebinin teşekkül ve gelişiminde oynadığı rol $^{43}$ göz önünde bulundurulduğunda bu durum daha da hayret verici bir durum arz etmektedir. Zira her ne kadar İbn Ömer hayatının tamamına yakınını Medîne'de geçirmiş olsa da İbn Mes'ûd, Hanefî mezhebinin ortaya çıtıı̆̆ Kûfe'de uzun bir süre yaşamış, ilmî faaliyetlerini burada sürdürmüştür. Bu yüzden rivayetin Hanefî bilginleri tarafindan bilinmiyor olması zayıf bir ihtimaldir. ${ }^{44}$ Nitekim Kudûrînnin (öl. 428/1037), et-Tecrîd isimli eserinde Ebû Hüreyre rivayetini zikrettikten hemen sonra rivayetin İbn Ömer tarikine de yer vermesi rivayetin kendilerine ulaşmamış olması ihtimalini ortadan kaldırmaktadır. ${ }^{45}$ Yine Serahsî de el-Mebsût isimli eserinde "Resûlullah'tan bize ulaştı ki (بلغنا عن رسول الشه)" şeklinde İbn Mes'ûd'un ismini zikretmeksizin ${ }^{46}$ rivayeti senedsiz olarak zikretmiştir.

Bu noktada bunun bilinçli bir tercih mi yoksa gözden kaçan bir husus mu olduğu sorusu akla gelmektedir. Özellikle İbn Mes'ûd rivayetine Buhârînin Sahîh'inde Ebû Hüreyre rivayetinden hemen sonra yer verilmesi ${ }^{47}$ ve lafız olarak Hanefî kaynaklarda geçmesine rağmen İbn Mes'ûd'un isminin zikredilmemesi, İbn Ömer rivayetinin Ebû Dâvud ve İbn Mâce'nin Sünenlerinde, ${ }^{48}$ Enes b. Mâlik tarikinin ise Beyhakî’nin es-Sünenü'l-Kübrầ'sında ${ }^{49}$ yer almasına rağmen rivayetin bu tariklerine değinilmemesi bunun bilinçli bir tercih olduğu izlenimi vermektedir.

Buhârîde İbn Mes'ûd'dan merfu olarak nakledilen musarrât hadisinin ${ }^{50}$ mevkuf yani İbn Mes'ûd'un kendi sözü olduğu söylenmektedir. Böyle olsa bile Abdullah b. Mes'ûd'un hem sahâbenin önde gelen fakihlerinden biri olması hem de Hanefî mezhebine olan kaynaklığı düşünüldüğünde bu görüşün mezhep için ne kadar önemli olduğu

${ }^{41}$ Yakub b. İbrâhîm Ebû Yûsuf, İhtilâfu Ebî Hanîfe ve İbn Ebî Leylâ, thk. Ebü'l-Vefâ el-Efgânî (b.y.: Matbaatü'l-Vefâ, 1357), 16; Muhammed b. Hasan eş-Şeybânî, Kitâbü'l-Asl: el-Mebsût, thk. Ebü'l-Vefâ elEfgânî (Beyrut: Âlemü'l-Kütüb, 1990), 5/117; Şemsüleimme Ebû Sehl Ebû Bekir Muhammed b. Ahmed es-Serahsî, el-Mebsût (Beyrut: Dâru'l-Ma'rife, ts.), 13/38.

42 Kâsânî, Bedâi 'u's-sanâi', 5/274; Abdulazîz el-Buhârî, Keşfu'l-esrâr, 3/537.

43 Bununla ilgili geniş bilgi için bk. Ahmet Yaman, “Abdullah b. Mes'ûd'un Hanefî Mezhebinin Oluşumundaki Rolü", Mârife, 4/2 (2004), 8-12.

44 Bk. Yaman, “Abdullah b. Mes'ûd'un Hanefî Mezhebinin Oluşumundaki Rolü”, 16.

45 Ebü'l-Hüseyin Ahmed b Ebî Bekr Muhammed b Ahmed Kudûrî, Mevsû‘atü'l-kavâidil'-fikhiyyeti'lmukârene: et-Tecrîd, thk. Muhammed Ahmed Sirac, Ali Cum'a Muhammed (Kâhire: Dârü's-Selâm, 2004), 5/2438 (مروى ابن عمر رضي الله عنها: أن النبي - صلى الله عليه وسلم - قال: من ابتاع محفلة فهو بالخيار ثلاثة أيام فإن ردها رد [معها] (مثل لبنها قمحاً.

46 Serahsî, el-Mebsût, 13/38.

47 Buhârî, "Buyû", 64. Rivayet ayrıca Ahmed b. Hanbel, Müsned, 7/171; İbn Ebî Şeybe, el-Musannef, 6/596; Abdürrezzâk, el-Musannef, 8/198 gibi temel hadis kaynaklarında da yer almaktadır.

48 Ebû Dâvud, "İcâre", 12; íbn Mâce, "Ticârât", 42.

49 Beyhakî, es-Sünenü'l-kübrâ, 5/319.

50 Buhârî, "Buyû", 64. Rivayetin kaynağı için ayrıca bk. Ahmed b. Hanbel, Müsned, 7/171-172 (Şuayb el-Arnaût hadisin sahih olduğunu söylemektedir); İbn Ebî Şeybe, el-Musannef, 6/596; Abdürrezzâk, el-Musannef, 8/198. 
izahtan varestedir. Ayrıca İmam Muhammed'in, fakih olması durumunda sahâbî sözünün kıyasa tercih edileceğ ${ }^{51}$ yönündeki yaklaşımı da mevkuf olduğu gerekçesiyle İbn Mes'ûd rivayetiyle amel edilmemiş olabileceği ihtimalini ortadan kaldırmaktadır. Hanefî usûlünde, bir sahâbînin kıyasa aykırı olan sözü/rivayeti, kendisine başka bir sahâbî muhalefet etmediği taktirde, o sözün Hz. Peygamber'den duyulmuş olması ihtimaline binaen, klyasa takdim edileceği bir kural olarak benimsenmiştir. ${ }^{52}$

Şâfiî fakihlerinden Zerkeşî (öl. 794/1392) de İbn Mes’ud rivayetinin/sözünün Hanefî bilginleri tarafından kabul edilmemesine dikkat çekerek şöyle demiştir: "Garip olan şey, onlarm (Hanefilerin) İbn Mes'ûd rivayetlerinin cümlesinden olan bu hadisi reddetmeleridir. Oysa onlara göre râvi İbn Mes'ûd gibi fakîh biri olduğunda, hadisi kıyasa muvafik olsun olmasin kabul edilir." ${ }^{33}$

Bu noktada musarrât hadisinin Ebû Hüreyre dışında diğer sahâbîlerden gelen üç tarikini burada vermek uygun olacaktır.

Buhârî̀de yer alan Abdullah b. Mes'ûd rivayeti şu şekildedir: ${ }^{44}$ "Kim sütü memesinde biriktirilmiş bir koyun satın almışsa (durumu öğrendiğinde isterse) o davarı geri versin ve onunla birlikte bir sấ da hurma versin (bazı rivayetlerde bir şeyler versin geçmektedir). $\mathrm{Hz}$. Peygamber mal satıcilarının yolda karşılanmasını yasaklamıştır. ${ }^{55}$

İbn Ömer rivayeti ise şöyledir: "Kim sütü memesinde biriktirilmiş bir hayvan satın alırsa (durumu öğrendiğinde) üç gün muhayyerdir. Dilerse reddeder. Sütün bir ya da iki misli de buğday verir." 56

Şu'ayb el-Arnaût senedde yer alan Cümey' b. Umeyr et-Teymî sebebiyle rivayetin zayıf olduğuna işaret etmiştir. ${ }^{57}$ Muhakkik Elbânî de rivayete zayıf hükmünü vermiştir. $^{58}$

Enes b. Mâlik rivayeti ise şöyledir: "Kim sütü memesinde biriktirilmiş bir koyun alırsa sahibi sütü sağıp (durumu öğrendiğinde) razı olursa onu tutsun, yoksa bir sa' hurma ile birlikte iade etsin." ${ }^{59}$

51 Bk. Serahsî, el-Mebsût, 6/10; Ebû Muhammed Bedreddin Mahmûd b. Ahmed b. Musa el-Aynî, el-

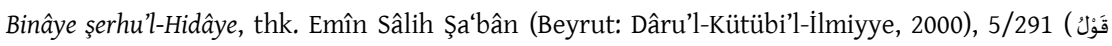

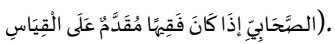

52 Yaman, "Abdullah b. Mes'ûd'un Hanefî Mezhebinin Oluşumundaki Rolü", 17.

53 Ebû Abdullah Bedreddin Muhammed b. Bahadır b. Abdullah Zerkeşî, el-Bahru'l-muhît fí usûli'l-fikh, haz. Abdülkadir Abdullah el-Ânî (Kuveyt: Vizâretü'l-Evkâf ve'ş-Şuûni'l-ìslâmiyye, 1992), 4/344.

54 Rivayetle ilgili değerlendirme için bk. Ebü'l-Fazl Şihâbüddîn Ahmed b. Alîb. Muhammed İbn Hacer el-Askalânî, Fethü'l-bârî Şerhu Sahîhi'l-Buhârî (Beyrut: Dâru'l-Ma'rife, 1379), 4/368.

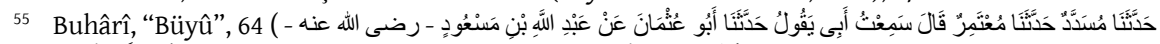

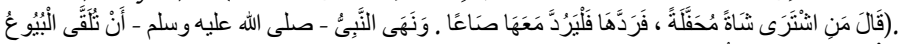

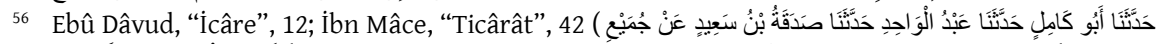

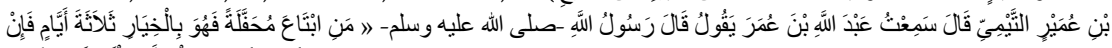

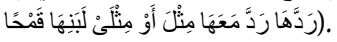

57 Ebû Dâvûd, Sünenü Ebî Dâvûd, thk. Şuayb el-Arnaût v.dğr. (Beyrut: Dâru'r-Risâleti'l-Âlemiyye, 2009), 5/318.

58 Ebû Dâvûd, Sünenü Ebî Dâvûd, thk. Muhammed Muhyiddin Abdülhamîd (Beyrut: el-Mektebetü'lAsriyye, ts.), 3/271.

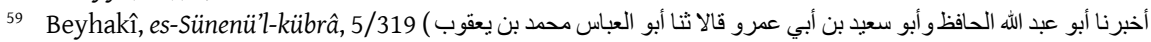
ثنا يحيى بن أبي طالب ح و أخبرنا أبو بكر بن الحسن القاضي و أبو سعيد بن أبي عمرو قالا ثنا أبو العباس الأصم ثنا محمد بن إبحاق 
Heysemî, hadisle ilgili değerlendirmesinde senedde yer alan İsmâ̂̂l b. Müslim el-Mekkînin zayıf olduğunu belirtmiştir. ${ }^{60}$

Hem İbn Ömer hem de Enes b. Mâlik rivayetlerinin zayıf olduğu ehli tarafından tespit edilmiştir. Ancak tartışmalı olmakla beraber hadis usûlünde mütâbi veya şâhidlerinin çoğalmasıyla birlikte zayıf hadis hasen li-gayrihi mertebesine yükselir. ${ }^{61}$

Her ne kadar son iki rivayet zayıf olsa da Ebû Hüreyre ve İbn Mes'ûd rivayetleri ile ilgili bir sıhhat problemi söz konusu değildir. Bütüncül bir şekilde rivayetlere bakıldığında musarrât/muhaffele hadisiyle amel edilmesinin önünde bir engel olmadığı görülmektedir. Çünkü sahih olan diğer iki rivayetle birlikte İbn Ömer ve Enes b. Mâlik rivayetleri de amel edilebilir seviyeye ulaşmıştır. Bunun neticesinde diyebiliriz ki, Ebû Hüreyre fakih olmadığı için bu rivayetle amel edilmediği şeklindeki bir temellendirme çok isabetli gözükmemektedir. Zira fakih olan İbn Mes'ûd ve İbn Ömer rivayetleri bu düşüncemizi desteklemektedir. Kaldı ki Ebû Hanîfe, Ebû Hüreyre'nin rivâyet ettiği musarrât hadisiyle muhayyerlik süresinin belirlenmesi bakımından amel etmiştir. Bu da rivayetin sıhhati konusunda herhangi bir problemin olmadı̆̆ını gösterir. Ebû Yûsufun naklettiğine göre müşteri ya da satıcının bir ay süreyle muhayyer oldukları bir satım akdini Ebû Hanîfe şu sözlerler geçersiz saymaktadır: "Bu alışveriş fasittir. Muhayyerlik süresi üç günden fazla olamaz. Resulullahtan (s.a.v.) bize ulaştığına göre o şöyle buyurmuştur: 'Kim sütü memesinde biriktirilmiş bir koyun/keçi satın almışsa üç gün içerisinde iki şey arasında muhayyerdir. (Dilerse akde rıza gösterir ve hayvanı alıkor) dilerse de hayvanı bir sấ hurma ya da arpa ile birlikte geri verir.' Ebu Hanîfe muhayyerliğin süresini belirlemede tümüyle Hz. Peygamber'in sözünü esas almıştır." ${ }^{62}$ Ayrıca İmameyn, Ebû Haniffe'nin muhayyerlik konusunda sürenin üç günle sınırlı olacağı görüşünün delilini bu hadisin oluşturduğunu söylemektedir. ${ }^{63}$ Yine Ebû Yûsuf da musarrât hadisini delil olarak kabul etmiş ve müşteriye muhayyerlik hakk1 tanımıştır. ${ }^{64}$ Tahâvînin kaydettiğine göre Ebû Yûsuf, el-Emâli'de musarrât hadisiyle ilgili olarak müşterinin durumunu öğrendikten sonra "hayvanı geri verir onunla birlikte bir sa" hurmanın da kıymetini verir. Ebû Hanîfe ve Muhammed ise ayıptan dolayı müşteri malı geri iade

(الصغاني قالا ثنا عبد الو هاب بن عطاء أنا إسماعيل بن مسلم عن الحسن Benzer bir rivayet için Nureddin Ali b. Ebî

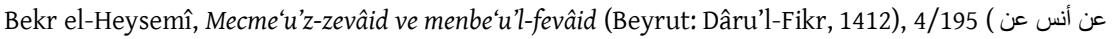
(النبي صلى الله عليه و سلم أنه نهى عن بيع المحفلات وقال من ابتاعهن فهو بالخيار إذا حلبهن

60 Heysemî, Mecmeu'z-zevâid, 4/195.

61 Bk. M. Emin Özafşar-Mahmut Demir, “Zayıf”, Türkiye Diyanet Vakfi İslam Ansiklopedisi (İstanbul: TDV Yayınları, 2013), 44/159.

62 Ebû Yûsuf, İhtilâfu Ebî Hanîfe ve İbn Ebî Leylâ, 16-17; Yiğit, Ebû Hanîfe'nin Usûl Anlayışında Sünnet, 237238, 286.

63 Ebû Yûsuf, İhtilâfu Ebî Hanîfe ve İbn Ebî Leylâ, 16-17; Şeybânî, Kitâbü'l-Asl, 5/117-118; Yiğit, Ebû Hanîfe'nin Usûl Anlayışında Sünnet, 286; Yarba, "Tartışmalı Bazı Hadisleri ve Fetvaları Bağlamında Ebû Hüreyre'nin Fakihliği Meselesi", 170.

64 Abdülazîz el-Buhârî, Keşfü'l-esrâr, 2/708; İbn Nüceym, Fethu'l-ğaffâr, 2/91; Ünal, İmam Ebû Hanîfe'nin Hadis Anlayışı, 184. 
edemez. Ancak aybın (kusurun) ölçüsü miktarınca ücretten indirim yapması için satıcıya müracaat edebilir" demiştir..$^{65}$

Hanefî fakihlerinden Muhammed b. Şücâ‘/İbnü’s-Selcî (öl. 266/880), Hz. Peygamber'in "Alıcı ve satıcı birbirlerinden ayrılmadıkça muhayyerdir" ha hadisinin musarrât hadisini nesh ettiğini; tarafların birbirinden ayrılmalarıyla -istisna etmeleri hariçmuhayyerlik haklarının kalmayacağını iddia etmiştir. ${ }^{67}$ Bu iddiayı Tahâvî (öl. 321/933) şu sözlerle eleştirmektedir: “Bu te’vil fasiddir. Çünkü musarrât hadisi için söz konusu edilen muhayyerlik, ayıp muhayyerliğidir. Ayı (kusur) muhayyerliği ise tarafların birbirlerinden ayrılmasıyla sona ermez. Müșterinin hayvanın söylendiği/göründüğü gibi sütlü olup olmadığını anlayabilmesi için bir kaç kez sağması gerekir. Bu da bir süreyi gerektirir. $O$ da üç gündür. Bu süre zarfinda eğer söylendiği gibi çıkarsa akid bağlayıcı hale gelir ve satış tamamlanmış olur. Eğer anlatılanın aksine bir durum ortaya çıkarsa, o zaman ayıp sabit olur ve müşterinin hayvanı geri iade etmesi gerekir. Eğer üç gün sağar ve bu sürenin sonunda aybın farkına varmasına rağmen sağmaya devam ederse artık buna razı olmuş demektir." ${ }^{68}$ Görüldüğü gibi Hanefî mezhebinde gerek kurucu imamlar gerekse daha sonraki fukahâ -en azından muhayyerliğin süresi konusunda- bu rivayetle amel etmişlerdir. Yani rivayeti tümden reddetme durumu söz konusu değildir. Bu rivayetle amel edilmediğini kabul etsek bile Pezdevînin söylediği gibi “Ashabımı bu tür rivayetlerle amel etmeyi ancak kitaba ve meşhur sünnete muhalefet ettiği için terk etmiştir. Yoksa râvileri fakih olma şartını taşımadıkları için değil. Nitekim musarrât hadisi kitap ve sünnetin zahirine aykırı olduğu için kendisiyle amel edilmemiştir." ${ }^{69}$

Yukarıdaki ifadeler de göstermektedir ki, kurucu imamlar için râvinin fakih olması, bir konudaki hadislerle amel etmede bir tercih sebebi olabilir. Yani fakih olan râvinin rivayeti fakih olmayana tercih edilebilir. Nitekim Hz. Ömer, Hz. Ali, İbn Mes'ûd gibi fikhıyla meşhur olan sahâbilerin rivayetleri diğerlerine tercih edilmiştir. Ancak kıyasla teâruz etmesi durumunda sırf râvisi fakih olmadı̆̆ı için kıyasın haberi vâhide tercih edilmesi görüşünün Hanefî mezhebinin bütün fakihleri tarafindan benimsenen bir görüş olduğunu söylemek mümkün değildir.

\section{Ebû Hüreyre'nin Fakih Olduğunu Savunananlar ve Görüşleri}

En eski tabakât kitaplarından biri olan et-Tabakâtu'l-kübrâ'nın müellifi İbn Sa'd (öl. 230/845), Ziyâd b. Mînâ'dan şu bilgiyi nakleder: "Hz. Osman vefât ettiğinde Medîne'de İbn Abbas, İbn Ömer, Ebû Saîd el-Hudrî, Abdullah b. Amr b. el-Âs, Ebû Hü-

65 Ebû Ca'fer Ahmed b. Muhammed b. Selâme Ezdî Hacrî Misrî Tahâvî, Şerhu Me âni'l-âsâr, thk. Muhammed Seyyid Ca'delhak, Muhammed Zührî en-Neccâr (Beyrut: Alemü'l-Kütüb, 1994), 4/19.

66 Buhârî, "Büyû", 44-45; Müslim, "Büyû", 43-46.

67 Tahâvî, Şerhu Me âni'l-âsâr, 4/19.

68 Tahâvî, Şerhu Me âni'l-âsâr, 4/19-20.

${ }^{69}$ Abdülazîz el-Buhârî, Keşfü'l-esrâr, 2/708; Kemâlüddîn Muhammed b. Abdilvâhid b. Abdilhamîd esSivâsî el-İskenderî İbnü'l-Hümâm, et-Tahrîr fi usûli'l-fikh (Mısır: Matbaatü Mustafa el-Bâbî el-Halebî, 1351), 319; Yarba, “Tartışmalı Bazı Hadisleri ve Fetvaları Bağlamında Ebû Hüreyre'nin Fakihliği Meselesi”, 162. 
reyre, Câbir b. Abdillah, Râfî̀ b. Hadîc, Seleme b. el-Ekva', Ebû Vâkıd b. el-Leysî, Abdullah b. Buhayne gibi sahâbîler hadis rivayet edip fetva veriyorlardı. Hayatlarının sonuna kadar da buna devam ettiler. Bunlar içerisinde fetva verme görevini daha ziyade üstlenenler ise İbn Abbas, İbn Ömer, Ebû Said el-Hudrî, Ebû Hüreyre ve Câbir b. Abdullah olmuştur."70

Hanefî fakihlerinden Kerhî, özellikle Ebû Hüreyre'nin fakih olmadığını gerekçe göstererek kıyasa aykırı bazı rivayetleriyle amel edilemeyeceğini savunan İsa b. Eban'a "Ebû Hüreyre nasıl fakih olamaz! Sahâbe zamaninda fetva veriyordu. O dönemde de ancak fakih olanlar fetva verebiliyordu"71 diyerek karşı çıkmakta ve Ebû Hüreyre'nin sahâbenin fakihlerinden olduğunu savunmaktadır. Pezdevî şârihlerinden Keşfü'l-esrâr müellifi Abdulazîz el-Buhârî (öl. 730/1330) de bu görüştedir. O, Ebû Hüreyre'nin fakih olmadığı iddiasının kabul edilemeyeceğini, içtihat için gerekli şartların eksiksiz olarak kendisinde mevcut olduğunu ve sahâbe içerisinde fetva verdiğine vurgu yaparak bu dönemde ancak fakih ve müçtehit olanların fetva verebildiğine dikkat çekmektedir. ${ }^{72}$ Gayetï't-tahkîk isimli eserinde de aynı ifadeleri kullanan Abdulaziz el-Buhârî, ayrıca hocalarından Takiyyüddîn es-Sübkînin (öl. 756/1355), Ebû Hüreyre'nin fetvalarını Fetâvâ Ebî Hüreyre ismiyle bir cüz halinde toplayıp bir araya getirdiğini bizzat kendisinden duyduğunu aktarmaktadır. ${ }^{73}$

Mâlikî fakihlerinden Karâfî (öl. 684/1285) ise konuyla ilgili olarak "Sahâbe, mü'minlerin iki emiri Hz. Ebû Bekir ve Hz. Ömer'den (r.a.) fetva isteyen ve onları taklid eden bir kimsenin Ebû Hüreyre, Muâz b. Cebel ve başka sahâbîlerden de fetva isteyebileceği ve onlarm görüşüyle amel edebileceği hususunda icma etmiştir. Eğer bir kimse bu icmanın ortadan kalktığını iddia ederse bunun için delil getirmesi gerekir"74 sözleriyle Ebû Hüreyre'nin de kendisinden fetva talep edilen birisi olduğuna dikkat çekmektedir.

70 Ebû Abdullah Muhammed b. Sa'd b. Menî ez-Zührî İbn Sa'd, et-Tabakâtu'l-kübrâ, thk. Ali Muhammed Ömer (Kâhire: Mektebetü'l-Hanc1, 2001), 2/321; Ebû İshâk Cemâlüddîn İbrâhîm b. Alî b. Yûsuf eş-Şîrâzî, Tabakâtü'l-fukahâ, thk. İhsan Abbas (Beyrut: Dâru'r-Râid el-Arabî, ts.), 51; Ebü'l-Kâsım Alî b. el-Hasen b. Hibetillâh b. Abdillâh b. Hüseyn ed-Dımaşkî İbn Asâkir, Târihu Dımaşk, thk. Muhibbüddin Ebî Saîd Ömer b. Garâme el-Amrî (Beyrut: Dârü'l-Fikr, 1995/1415), 22/103; Şemseddin Muhammed b. Ahmed b. Osman ez-Zehebî, Siyeru a'lâmi'n-nübelâ, thk. Beşşar Avvad Ma'ruf(Beyrut: Müessesetü’r-Risâle, 1996), 2/606-607; İbn Hacer, el-İsâbe, 1/75; Muhammed Accâc el-Hatîb, es-Sünne kable't-tedvîn (Beyrut: Dâru'l-Fikr, 1980), 428; Abdüssettâr eş-Şeyh, Ebû Hüreyre râviyetü'l-İslâm ve seyyidül-huffâzi'l-esbât (Dımaşk: Dârü'l-Kalem, 2003), 309; Kandemir, "Ebû Hüreyre", 10/162.

71 Aynî, Umdetü'l-kâri', 12/339.

72 Abdulazîz el-Buhârî, Keşfü'l-esrâr, 2/708. Ayrıca bk. Ebü'l-Muzaffer Mansûr b. Muhammed b. Abdilcebbâr Temîmî Mervezî Sem‘ânî, Kavâtü̈l-edille fi'l-usûl, thk. Muhammed Hasan İsmail eş-Şâfîi (Beyrut: Dâru'l-Kütübi'l-İlmiyye, 1997), 1/364; Muhammed Emin b. Mahmûd Buhârî Emir Padişah, Teysîrü't-tahrîr şerhu alâ Kitâbi't-tahrîr (Mekke-i Mükerreme: Dâru'l-Bâz, ts.), 3/53; Zerkeşî, Bahrü'lmuhît, 6/212; Yarba, "Tartışmalı Bazı Hadisleri ve Fetvaları Bağlamında Ebû Hüreyre'nin Fakihliği Meselesi”, 162.

73 Kureşî,el-Cevâhirü'l-mudıyye, 4/541;Zerkeşî, el-Bahru'l-muhît, 6/212; Hacı Halife Mustafa b. Abdullah Kâtib Çelebi, Süllemü'l-vüsûl ilâ tabakâti'l-fuhûl, thk. Mahmud Abdülkadir el-Arnaût (İstanbul: Ma'hedü'l-Buhûs ve'd-Dirâsati'l-Arabiyye/IRCICA, 2010), 5/427; Kandemir, "Ebû Hüreyre”, 10/162; Yarba, “Tartışmalı Bazı Hadisleri ve Fetvaları Bağlamında Ebû Hüreyre'nin Fakihliği Meselesi”, 173.

74 Şihâbuddîn Ahmed b. İdris Karâfî, ez-Zehîra, thk. Muhammed Haccî (Beyrut: Dâru'l-Garbi'l-İslâmî, 1994), 1/141; Ebû Abdillâh Şemsüddîn Muhammed b. Muhammed b. Muhammed el-Halebî İbn 
Aynı şekilde Zâhirî mezhebinin sembol ismi İbn Hazm ez-Zâhirî (öl. 456/1064) ile Hanbelî fakih ve usulcülerinden İbn Kayyim el-Cevziyye (öl. 751/1350) sahâbeyi fetvâları bakımından müksirûn, mütevassitûn ve mukillûn olmak üzere üç kategoriye ayırmışlardır: Ebû Hüreyre'yi, Hz. Ebû Bekir, Hz. Osman, Enes b. Mâlik, Ebû Saîd elHudrî, Abdullah b. Zübeyr, Ebû Mûsa el-Eş‘arî, Muaz b. Cebel, Sa'd b. Ebî Vakkâs gibi sahâbenin önde gelenleriyle birlikte mütevassitûn grubu içerisinde zikretmişlerdir. Bu grupta yer alanların sayıları on üç kişi olup, her birinin verdiği fetvaların bir araya getirildiğinde bir cilt kadar olacağını ifade etmişlerdir. ${ }^{75}$

Siyeru 'alâmi'n-nübelâ isimli eserinde Ebu Hüreyre'den bahsederken söze, "elİmâm, el-fakîh, el-müctehid, el-hâfiz..." "76 diye başlayan Zehebî (öl. 748/1348), Ebû Hüreyre'nin de tıpkı İbn Abbas gibi pek çok zor ve incelik isteyen meselede fetva verdiğini kaydetmektedir. ${ }^{77}$ Zehebî bir diğer eseri Tezkiratü'l-huffâz'da ise Ebû Hüreyre'yi "el-fakîh" diye nitelendirdikten sonra fetva veren imamların büyükleri arasında zikretmektedir. ${ }^{78}$

Tirmizî şârihi Mübârekpûrî (öl. 1935) de, bazı Hanefî fakihlerinin Ebû Hüreyre'yi fakih olarak kabul etmemelerini eleştirerek bu iddianın dayanaktan yoksun olduğuna işaret etmektedir. ${ }^{79}$

Bahrülulûm el-Leknevî (öl. 1225/1810) Ebû Hüreyre'nin müctehid bir fakih olduğunu, fakihliği konusunda herhangi bir şüphenin bulunmadığını; onun Hz. Peygamber hayattayken de sonrasında da fetva verdiğini; ayrıca zaman zaman İbn Abbas'ın görüş ve fetvalarına karşı çıktığını yani kendi görüşünü ortaya koyduğunu kaydetmektedir. ${ }^{80}$ İbn Sa'd'dan Bahrülulûm el-Leknevî’ye kadar pek çok

Emîru Hâc, et-Takrîr ve't-tahbîr (Beyrut: Dâru'l-Kütübi'l-îlmiyye, 1999), 3/449; Abdülali Muhammed b. Nizameddin Muhammed Sehâlevî el-Ensârî el-Leknevî, Fevâtihü'r-rahamût bi-şserhi Müsellemi'ssübût (Beyrut: Dâru'l-Kütübi'l-İlmiyye, 2002), 2/180; Muhammed Abdülhay b. Abdilkebîr b. Muhammed Hasenî İdrîsî Kettânî, Nizamü'l-hükümeti'n-nebeviyye: et-Terâtibül-idâriyye, thk. Abdullah el-Hâlidî (Beyrut: Dâru'l-Erkâm, ts), 2/271; a.mlf. et-Terâtibü'l-idâriyye: Hazreti Peygamber'in Yönetiminde Sosyal Hayat ve Kurumlar, çev. Ahmet Özel (İstanbul: İz Yayıncıllk, 1993), 3/209.

75 Ebû Muhammed Ali b. Ahmed b. Saîd ỉbn Hazm, el-ìhkâm fi usûli'l-Ahkâm, thk. Mahmud Hamid Osman (Kâhire: Dâru'l-Hadîs, 2005), 704; İmâmü'l-Haremeyn Ebü'l-Meâlî Rüknüddîn Abdülmelik b. Abdullâh b. Yûsuf Cüveynî, Nihâyetü'l-matlab fidirâyeti'-mezheb, thk. Abdülazîm Mahmud ed-Dîb (Beyrut: Darü'l-Minhac, 2007/1428), 1/79 (Mukaddime); Ebû Abdullah Şemseddin Muhammed İbn Kayyim el-Cevziyye, I'lâmu'l-muvakkiî̀n an Rabbil-âlemîn, thk. Muhammed Abdüsselam İbrâhim (Beyrut: Dârul'-Kütübi'l-illmiyye, 1991/1411), 2/10; Ebü'l-Fazl Celaleddin Abdurrahman b. Ebî Bekr es-Suyûtî, Tedrî̉ürr-râvî fi șerhi Takrîbin-Nevevî, thk. Abdülvehhab Abdüllatif (Riyâd: Mektebetü'r-Riyâd, ts.), 2/219; İzmirli İsmail Hakk1, İlm-i Hilâf, haz. Sirrı Fuat Ateş (Konya: Hüner Yayınevi, 2012), 2/19; Şeyh, Ebû Hüreyre, 310; Kandemir, "Ebû Hüreyre", 10/162.

76 Zehebî, Siyer, 2/578.

77 Zehebî, Siyer, 2/620; Muhammed Accâc el-Hatîb, Ebû Hüreyre râviyetü'l-İslâm (b.y.: Mektebetü Vehbe, 1982), 129; Şeyh, Ebû Hüreyre, 310.

78 Zehebî, Tezkiratü'l-huffâz, 1/32; Şeyh, Ebû Hüreyre, 310.

79 Ebü'l-Ali Muhammed Abdurrahman b. Abdurrahîm Mübârekpûrî, Tuhfetü'l-ahvezî bi-şerhi Câmii'tTirmizî (Dımaşk: Dâru'l-Fikr, ts.), 1/32.

80 Leknevî, Fevâtihü'r-rahamût, 2/180; Kettânî, et-Terâtibü'l-idâriyye, 2/271; a.mlf. Hazreti Peygamber'in Yönetiminde Sosyal Hayat, 3/209. 
ilim adamına göre her ne kadar Hz. Ömer, Hz. Ali, İbn Mes'ûd, İbn Ömer, İbn Abbas gibi fikhılla meşhur ve maruf olmasa da Ebû Hüreyre'nin fakihliğinin sahâbe içerisinde tartışılmayan bir konudur.

Çağdaş müelliflerden Muhammed Accâc el-Hatîb'in Ebû Hüreyre'ye hasrettiği çalışmasında konuyla ilgili şu değerlendirmesi önem arz etmektedir: "Ebû Hüreyre sadece hadis rivayet etmemiştir. Bilakis o, Kur'an, Sünnet ve ictihadda da döneminin önde gelen ilim adamlarından birisi olmuştur. Çünkü Peygamber (s.a.v.) ile olan birlikteliği ve sohbetlerine devamlliğı onun din konusunda ince anlayış, derin kavrayış (tefakkuh) sahibi olmasına imkân sağlamıştır. O her yönüyle amelî (yaşayan) sünnete şahitti. o, Peygamber'den (s.a.v.) çok şey ezberlemiştir. Bu da hadisi şerifler konusunda büyük bir birikiminin oluşmasını sağlamıştır. Böylece o, Peygamber (s.a.v.) döneminde Müslümanlar arasında ortaya çıkan pek çok şer'îmeselenin çözümüne muttali olmuştur. Bütün bunlar, dinleri konusunda müslümanlara yirmi yıldan fazla fetva verecek şekilde Ebû Hüreyre'yi hazırlamıştır. Ziyâd b. Mînâ'nın haber verdiğine göre o esnada İbn Abbas, İbn Ömer, Ebû Saîd el-Hudrî, Ebû Hüreyre, Câbir ve daha onlar gibi pek çok sahâbî (r.a.) Medîne'de fetva veriyorlar ve Hz. Peygamber'den hadis naklediyorlardı. Ziyad b. Mînâ, ayrıca bu beş kişinin $\mathrm{Hz}$. Osman'in ölümünden vefâtlarına kadar fetva vermeye devam ettiklerini de kaydetmektedir." ${ }^{81}$ Bütün bu bilgiler gösteriyor ki, Ebû Hüreyre, sadece hadis rivayetiyle meşgul olmamış, aynı zamanda Hz. Peygamber'le olan birlikteliği, Resûlullah'ın kendisine yöneltilen hukûkî meseleleri çözüme kavuşturmasına şahit olması Ebû Hüreyre'nin yöntem ve hukuk nosyonu/birikimi elde etmesine imkân sağlamıştır. Bunlardan hareketle Ebû Hüreyre'nin Hz. Peygamber'in vefâtından sonra Medîne'deki fetva otoritelerinden biri haline geldiğini söylemek mümkündür. Nitekim İbn Abbas'ın kendisine yöneltilen zor ve içinden çıkılmaz meseleleri "o sana yeter" diyerek soran kimseleri çözüm için Ebû Hüreyre'ye yönlendirmesi, fetva konusunda ona verdiği değerin bir göstergesidir. $^{82}$

Ayrıca gerek Hz. Ebû Bekir'in irtidad olayları sırasında Ebû Hüreyre'yi, Alâb. Hadramîyyle birlikte Bahreyn'e göndermesi ${ }^{83}$ gerekse Hz. Ömer'in hilafeti esnasından Kudâme b. Maz'un'u zekat ve vergi âmili olarak Bahreyn'e gönderirken Ebû Hüreyre'yi de kazâ ve yargı işleriyle ilgilenmek üzere görevlendirmesi ve daha sonra Bahreyn'e vali olarak tayin etmesi, Ebû Hüreyre'nin fikıh konusundaki bilgi ve birikimine güvendiklerini göstermektedir. ${ }^{84}$ Ebû Hüreyre'nin Bahreyn'e kaza ve yargı işlerini yürütmek için gönderilmesini Abdurrahman el-Muallimî el-Yemânî şöyle değerlendirmektedir: " $\mathrm{Hz}$. Ömer’in kaza ve namaz kıldırma vazifelerini ilk Müslümanlardan ve Bedir ehlinden olmasına ră̆men Kudâme b. Maz'un'a bırakmayıp bu işiçin Ebû Hüreyre’yi görevlendirmesi, onun sahâbenin

81 el-Hatîb, Ebû Hüreyre, 128; a.mlf. es-Sünne, 428.

82 Şeyh, Ebû Hüreyre, 308; Kandemir, "Ebû Hüreyre", 10/165.

83 İbn Hacer, el-İsâbe, 7/360; Kandemir, "Ebû Hüreyre”, 10/160-161.

84 Ebü'l-Abbas Ahmed b. Yahyâ b. Câbir Belâzürî, Fütûhu'l-büldân (Beyrut: Dâru Mektebeti'l-Hilâl, 1988), 1/88-89; İbn Hacer, el-İsâbe, 5/425; Şeyh, Ebû Hüreyre, 309; Kandemir, "Ebû Hüreyre”, 10/161. 
âlimlerinden olduğunun kesin delilidir. Hz. Ömer ilk Müslümanları ve Bedir ehlini en iyi bilenlerden birisiydi." $" 5$

\section{Ebû Hüreyre'nin Verdiği Fetvalara Örnekler}

Ebû Hüreyre'nin farklı konularda verdiği pek çok fetva vardır. Yukarıda da ifade edildiği gibi Abdulaziz el-Buhârî, hocası Takiyyüddîn es-Sübkînin, Ebû Hüreyre'nin fetvalarını Fetâvâ Ebî Hüreyre ismiyle bir cüz halinde topladığını bizzat kendisinden duyduğunu aktarmaktadır. ${ }^{86}$ Ancak bu eserin günümüze ulaşıp ulaşmadığı bilinmediği için Ebû Hüreyre'nin fetvalarına derli toplu olarak ulaşmak mümkün gözükmemektedir. Farklı kaynaklardan derleyebildiğimiz fetva örneklerini burada kaydetmeye çalışacağı.

\section{1. Üçten Az Boşamalarda Kadının Başka Biriyle Evlenmesinin Önceki Evlilikten} Kalan Talak Haklarına Etkisi

Ebû Hüreyre Hz. Ömer tarafından Bahreyn'e vali olarak tayin edildiği zaman kendisine, bir talakla boşanıp sonra başkası tarafından nikâhlanıp zifafın akabinde kendisinden ayrılan ve tekrar ilk kocasıyla evlenen bir kadının kaç talak hakkıyla kocasına döneceği sorusu sorulmuştur. Ebû Hüreyre de bu soruya üçe varmayan boşama kocaya hanımını haram kılmaz. Bu yüzden ikinci kocanın kadınla takarrübü hiçbir şeyi ortadan kaldırmaz. Yani kocanın kaç hakkı kalmışsa onunla devam ederler cevabını vermiştir. Hz. Ömer de bu fetvasını olumlu bulduğunu ifade etmiştir. ${ }^{87} \mathrm{Bu}$ görüş aynı zamanda sahâbeden Hz. Ömer, Hz. Ali, Ubey b. Kâ‘b ve İmran b. Husayn'in da görüşüdür. Hanefî fakihlerinden Züfer ve İmam Muhammed ile İmam Şâfiî de bu görüşü benimsemiştir. ${ }^{88}$

\subsection{Zifaftan Önce Üç Kere Boşanan Kadının Durumu}

Muhammed b. İyas b. el-Bükeyr'in naklettiğine göre adamın biri zifafa girmeden hanımını üç talak ile boşadıktan sonra tekrar onunla evlenmek istedi. Bunun üzerine bana fetva sormaya geldi. Birlikte Abdullah b. Abbas ve Ebû Hüreyre'ye gittik. Adam

85 Abdurrahman b. Yahya el-Muallimî el-Yemânî, el-Envârü'l-kâşife limâ fì kitâbi edva ale's-sünne mine'z-zelel ve't-tadlîl ve'l-mücâzefe (Beyrut: Alemü'l-Kütüb, ts.), 205. Bu eser, Ebû Reyye'nin (ö. 1970 Ebû Hüreyre'ye özel başlık açarak kendisine bazı eleştiri ve ithamlarda bulunduğu Edvâ' ale's-sünneti'l-Muhammediyye ev difấ ' ani'l-hadîs isimli eserine reddiye olarak kaleme alınmıştır. Bk. Bayram Kanarya, "Ebû Reyye'nin Bazı Temel Hadis Meseleleri İle İlgili İddialarına İbn Yahya’nın Verdiği Cevaplar”, Dicle Üniversitesi Sosyal Bilimler Enstitüsü Dergisi, 16 (2016), 151.

86 Kureşî, el-Cevâhirü'l-mudryye, 4/541; Zerkeşî, el-Bahru'-muhît, 6/212; Kâtib Çelebi, Süllemü'l-vüsûl, 5/427; Kandemir, "Ebû Hüreyre”, 10/162; Yarba, "Tartışmalı Bazı Hadisleri ve Fetvaları Bağlamında Ebû Hüreyre'nin Fakihliği Meselesi", 173.

87 Zehebî, Siyer a'lâmi'n-nübelâ, 2/619-620; Zeylâ̂, Nasbu'r-râye, 3/240-241; Hatîb, Ebû Hüreyre, 129; Şeyh, Ebû Hüreyre, 318-319.

88 Serahsî, el-Mebsût, 6/95. 
meseleyi onlara sordu. Onlar da, "Kadın başka birisiyle evlenmeden onunla tekrar evlenemezsin" dediler. O da, ben onu yalnız bir talakla boşadım deyince İbn Abbas, "Nimeti elinden kaçırdın" cevabını verdi. ${ }^{89}$

Yine benzer bir rivayete göre Muaviye b. Ebî Ayyaş el-Ensârî dedik ki: Ben Abdullah b. Zübeyr ve Âsım b. Ömer b. el-Hattâb'ın yanındaydım. Yanımıza Muhammed. b. İyâs b. el-Bükeyr gelerek şöyle dedi: "Bir bedevi nikahtan sonra karısina yaklaşmadan onu üç talak ile boșadı. (Bu hususta) görüşünüz nedir?” Abdullah b. Zübeyr, "bu konuda diyeceğim bir şey yoktur. Sen Abdullah b. Abbas ve Ebû Hüreyre'ye git. Onlar Âişe’nin yanındadırlar. Onlara sor sonra gel neticeyi bize bildir" dedi. Adam gitti, onlara sordu. İbn Abbas, Ebû Hüreyre'ye "İşte karmaşık bir mesele geldi, fetvasını ver" deyince, Ebû Hüreyre, "Bir talak ile onu boş yapar (yani yeniden evlenebilirler). Üç talak da başka kocaya varıncaya kadar o kadının tekrar nikah edilmesini haram kılar" cevabını verdi. İbn Abbas da aynısını söyledi. ${ }^{90}$

\subsection{Boşama Yetkisini Kullanmadan Kocasına Iâade Eden Kadının Durumu}

Abdullah b. Ömer ile Ebû Hüreyre'ye, boşama yetkisini karısına veren, bu yetkiyi kullanmadan kocasına iade eden kadının boşanmış sayılıp sayılmayacă̆ı hakkında fetva soruldu. Her ikisi de: "Bu boşama saylmaz" dediler. ${ }^{91} \mathrm{~Hz}$. Ali, İbn Mes'ûd, İbn Ömer de "bu durumda kadın kocasını tercih etmiştir. Ortada bir boşama olmadığı için talak da söz konusu değildir" demişlerdir. ${ }^{92}$

\section{4. İhramlının Av Eti Yemesinin Hükmü}

Ebû Hüreyre Bahreyn yolundayken Rebeze'ye vardığında Irak'tan gelen ihramlı bir kafile kendisine Rebezeli birinden aldıkları av etinden yiyip yiyemeyeceklerini sorarlar. Ebû Hüreyre yiyebilecekleri cevabını verir. Ancak daha sonra verdiği fetvâ konusunda şüpheye düşer. Medine'ye gelince durumu Hz. Ömer'e anlatır. Hz. Ömer kendisine ne cevap verdiğini sorunca o da, yiyebileceklerini söylediğini anlatır. Bunun üzerine Hz. Ömer, "eğer başka türlü bir cevap verseydin sana neler yapardım (yani cezalandırırdım!)" karşılığını verir. ${ }^{93}$ Bu örnek Ebû Hüreyre'nin Hz. Ömer döneminde fetva verdiğini, fetva konusunda dikkatli davrandığını, zaman zaman da ihtiyatın bir gereği olarak konuyu Hz. Ömer'le müzakere ettiğini göstermektedir. ${ }^{94}$ Ebû Hüreyre'nin verdiği bu fetvânın sahâbenin önde gelen fakihlerinden olan Hz. Ömer'in fetvasıyla

89 Mâlik, Muvatta‘, “Talâk”, 15 (No. 1308); Tahâvî, Şerhu Me âni'l-âsâr, 3/57; Beyhakî, es-Sünenü’l-kübrâ, 7/552-553; Şeyh, Ebû Hüreyre, 317.

90 Mâlik, Muvatta' “Talâk” 15 (No. 1310); Tahâvî, Şerhu Me ânil-âsâr, 3/57; Şeyh, Ebû Hüreyre, 318; Kandemir, "Ebû Hüreyre", 10/162.

91 Mâlik, Muvatta،, "Talâk”, 5 (No. 1281); Beyhakî, es-Sünenül-kübrâ, 7/570; İbn Abdülber, el-İstizkâr, 6/31; Şeyh, Ebû Hüreyre, 317.

92 İbn Abdülber, el-İstizkâr, 6/31.

93 Mâlik, Muvatta' "Hac”, 24 (No. 850); Yakub b. İbrâhim Ebû Yûsuf, Kitâbü'l-Âsâr, haz. Ebü'l-Vefâ elEfgânî (Beyrut: Dâru'l-Kütübi'l-i̇lmiyye, ts.), 107-108; Şeybânî, Kitabu'l-Hucce, 2/157-158; 2/161-162; 2/165-166; Beyhakî, es-Sünenü'l-kübrâ, 5/309; Hatîb, Ebû Hüreyre, 129.

94 Şeyh, Ebû Hüreyre, 316. 
uyum arz etmesi, onun sahip olduğu hukuk nosyonunu göstermesi açısından önem arz etmektedir. ${ }^{95}$ Ebû Hüreyre'nin Hz. Ömer'e fetvasının doğruluğunu test ettirmesi, fikhî konularda Hz. Ömer’i üstad kabul ettiğini göstermektedir.

\subsection{Boğazlanıp Eti Seğiren Hayvanın Durumu}

Akîl b. Ebî Tâlib'in azatlısı Ebû Mürre'nin naklettiğine göre Akîl, Ebû Hüreyre'ye (ölmek üzere iken) boğazlanan bir hayvanın vücudunda hareket varsa hükmünün ne olacağını yani etinin yenilip yenilmeyeceğini sorar. Bunun üzerine Ebû Hüreyre yenilebileceği cevabını verir. Aynı soruyu Zeyd b. Sabit'e de soran Akîl, "Boğazlanan hayvanın organları öldükten bir süre sonra elbette titrer. Kesmenin ona faydası yoktur. Sen bu vaziyette iken onu yeme!" cevabını verdiğini aktarır. Bu bilgiyi aktaran İmam Malik kendisine, yüksekten düşüp sakatlanan ve sahibinin derhal koşup boğazladığı, ancak sadece kan akıttığı, kendisinde hareket olmayan hayvanın durumu hakkındaki bir soruya "Sahibi onu kesti, hayvanın da kanı aktı, eğer hareket ediyordu ise onun etini yesin” cevabını vererek Ebû Hüreyre'nin görüşüyle amel etmiştir. ${ }^{96}$ Sahâbe arasındaki genel kanaatin de Ebû Hüreyre'nin görüşü doğrultusunda olduğu görülmektedir. Muvatta‘ şarihlerinden Zürkânînin kaydettiğine göre İbn Abdülber "Sahâbeden Zeyd b. Sâbit'in görüşünü benimseyen/ona muvafik kimseyi bilmiyorum. Ebû Hüreyre, İbn Abbas ve pek çok kişi ona muhalefet etmişlerdir" demiştir. ${ }^{97}$

Hanefî fakihlerinden İmam Muhammed de bu konuda Ebû Hüreyre'nin fetvasına benzer bir görüş ortaya koymuş ve ölmek üzere olan hayvanın boğazlanmasıyla ilgili olarak "Eğer hayvan hareket ediyorsa kanaatime göre büyük ihtimalle o canlıdır, yenilebilir. Eğer seğirmeye benzer bir hareketse o leştir, yenmez"98 demiştir.

\section{6. İhramlıyken Hanımıla Takarrübda Bulunan Kimsenin Durumu}

Hz. Ömer, Hz. Ali ve Ebû Hüreyre'ye (r.a.), hac için ihrama giren kimsenin han-mıyla cinsel ilişkiye girmesi hakkında soruldu. Onlar da "Haccını îfaya devam eder, ancak gelecekyl tekrar hac yapması ve kurban kesmesi gerekir" diye cevap verdiler. Hz. Ali ayrıca şunu da ilave etti: "Gelecek seneki hacda, hacci tamamlayıncaya kadar kart-koca birbirlerine yaklaşmazlar." 99

95 Şeyh, Ebû Hüreyre, 310.

96 Mâlik, Muvatta' "Zebâih" 3 (No. 1152); İbn Ebî Şeybe, el-Musannef, 5/395; Abdürrezzak, el-Musannef, 4/499; Ebû Ömer Cemaleddin Yûsuf b. Abdullah b. Muhammed Kurtubî en-Nemerî İbn Abdülber, el-İstizkâr (Beyrut: Dâru'l-Kütübi'l-i̇lmiyye, 2002), 5/260; Ebû Abdullah Muhammed b. Abdülbaki b. Yûsuf Zürkânî, Şerhu'z-Zürkânî alâ Muvattai İmam Mâlik, thk. Taha Abdurrauf Sa'd (Kâhire: Mektebetü's-Sekâfeti'd-Dîniyye, 2003/1424), 3/127; Şeyh, Ebû Hüreyre, 319.

97 İbn Abdülber, el-İstizkâr, 5/261; Zürkânî, Şerhu'z-Zürkânî, 3/127.

98 Mâlik, Muvatta rivâyetü Muhahammed b. el-Hasan eş-Şeybânî, thk. Abdülvehhâb Abdullatîf, (Kâhire: el-Mektebetü'l-i̇lmiyye, 1994), 224.

99 Mâlik, Muvatta;, "Hacc”, 48 (No. 933); Beyhakî, es-Sünenül-kübrâ, 5/167; Ebû Muhammed Cemâlüddîn Abdullah b. Yûsuf b. Muhammed ez-Zeylâi, Nasbu'r-râye li tahrîci ehâdisi'l-Hidâye (Cidde: Müessesetü'r-Reyyân, ts.), 3/126; Şeyh, Ebu Hüreyre, 316-317. 


\subsection{Allah Yoluna Tahsis Edilen Malların Zekatı}

Ebû Ubeyd Kâsım b. Sellâm'ın (öl. 224/838) naklettiğine göre bir adam İbn Abbas'a gelerek şöyle dedi: Develerimden on tanesini Allah yoluna tahsis ettim/ayırdım. Bunlar için bana zekat düşer mi? İbn Abbas, "Ey Ebû Hüreyre! Âişe'nin evindekinden aşağı kalmayan (zorlukta) bir soru cevap ver" dedi. Bunun üzerine Ebû Hüreyre şöyle dedi: Allah'in yardımını dilerim ki, sana zekat yoktur. İbn Abbas, "isabet buyurdun, sırtında yük taşınmayan, sütünden istifade edilmeyen, yavrusu sahiplenilmeyen hiçbir hayvan için zekat yoktur" dedi. Bunun üzerine Abdullah b. Amr da, ikiniz de isabet ettiniz diyerek bu hükmü teyid etmiştir. ${ }^{100}$

\subsection{Kocası Hamile Kadının İddeti}

Abdullah b. Abbas ve Ebû Hüreyre'ye kocası ölen hamile kadının iddeti soruldu. İbn Abbas, "iki iddetten hangisi daha uzunsa o kadar beklemesi gerekir" dedi. Ebû Hüreyre ise "çocuğu doğurduğunda başkasılla evlenebilir" cevabını verdi. ${ }^{101}$

Fakihlerin çoğuna göre kocası ölen hamile kadınların iddetini tayin eden Talâk sûresi 4. ayet daha önce nâzil olan Bakara sûresi 234. Ayetin hükmünü hamile kadınlar açısından sınırlandırmaktadır. Bu sebeple kocası ölen hamile bir kadın kısa bir süre sonra doğum yapsa bile iddeti doğumla birlikte sona erer. Ancak Hz. Ali ve İbn Abbas ile İbn Ebû Leylâ ve Sahnûn gibi bazı fakihler ise her iki âyetin hükmünü de koruyabilmek için birini diğgerine tercih yerine ikisini birleştirme usulünü benimseyip kocası ölen hamile kadının hangi iddet süresi geç bitecekse ona tâbi olacağını söylemiştir. ${ }^{102}$

\subsection{Yaranın Ağzından Taşan Şeylerin Abdeste Etkisi}

Vücuttaki yaradan kan, sarı su ve irin gibi şeylerin yaranın ağzından taşması durumunda abdesti bozup bozmayacağı konusunda iki görüş ortaya çıkmıştır. Hz. Ali ve İbn Mes'ûd'a göre bunlar abdesti bozar. Bu Hanefilerin de benimsediği görüştür. İbn Abbas ve Ebû Hüreyre'ye göre ise abdest bozulmaz. Bu da Şâfiî hukukçuların benimsediği bir görüștür. ${ }^{103}$ Görüldüğü gibi Hanefî fikıh kitaplarında da Ebû Hüreyre'nin çeşitli fikhî meselelerdeki görüşlerine rastlamak mümkündür. Bu da, Ebû Hüreyre'nin sahâbenin fakihlerinden biri olduğunun önemli bir delilidir.

\subsection{Telef Olan Âriyetin Tazmini}

Mutlak olarak âriyet (ödünç) akdi yapılan bir maldan müsteîr (ödünç alan) kimse, muîr (ödünç veren) hayvanını geri istemediği müddetçe istifade edebilir. Ancak o malı başkasına kiraya veremez. (...) Ödünç alan kiraya vermeyip de gerek kullanım esnasında gerekse kullanım dışında malın telef olması halinde Hz. Ömer, Hz. Ali

\footnotetext{
100 Kâsım b. Sellâm el-Herevî el-Ezdî Ebû Ubeyd, Kitâbü'l-Emvâl, thk. Halil Muhammed Herrâs (Beyrut: Dâru'l-Fikr, ts.), 595; Şeyh, Ebû Hüreyre, 319-320.

101 Mâlik, Muvatta' "Talâk", 30 (No. 1361).

102 H. İbrahim Acar, “İddet”, Türkiye Diyanet Vakfi İslam Ansiklopedisi (İstanbul: TDV Yayınları, 2000), 21/467-468.

103 Serahsî, el-Mebsût, 1/76.
} 
ve İbn Mes ûd'a göre tazmin edilmez. Bu aynı zamanda Hanefî ulemasının görüşüdür. İbn Abbas ve Ebû Hüreyre'ye göre ise mutad kullanım esnasında telef olmuşsa müsteîr tazmin etmez. Ancak mutad kullanım durumunda olmaksızın telef olması halinde malın kıymetini tazmin eder. Bu aynı zamanda İmam Şâfî̂̀nin de görüşüdür. ${ }^{104}$

\section{Sonuç}

Ebû Hüreyre'nin hadis konusunda otorite olduğu herkes tarafından kabul edilen bir gerçektir. Her ne kadar sahâbe tarafından bazı rivayetleri sebebiyle tenkide uğramış olsa da, onun hadis konusundaki yetkinliği ve otorite oluşu Abdullah $b$. Ömer, Zeyd b. Sâbit, Talha b. Ubeydullah gibi sahâbîlerce ortaya konulmuştur.

F1kıh konusundaki yetkinliğine gelince, özellikle bazı Hanefî hukukçular tarafindan Ebû Hüreyre'nin sahâbenin fakihlerinden olmadığı, bu yüzden de mezhep içerisinde bazı rivayetlerinin kıyasa aykırı olması sebebiyle terk edildiği ifade edilmiştir. Buna gerekçe olarak da fakih olmaması sebebiyle Ebû Hüreyre'nin muâmelâta dair bazı rivayetleri ya eksik ya da yanlış anlamış olabileceği gösterilmiștir. Ancak yukarıdaki fetvâörnekleri Ebû Hüreyre'nin sahâbenin fakihlerinden birisi olduğunu göstermektedir. Nitekim Hz. Ömer' in kendisini Bahreyn'e kaza ve yargı işleriyle ilgilenmek üzere görevlendirmesi, Ebû Hüreyre'nin fıkıh nosyonuna ve birikimine güvendiğini göstermektedir. Bununla birlikte Hz. Ömer, Hz. Ali, İbn Ömer, Zeyd b. Sabit, İbn Abbas gibi sahâbeden fikhıla maruf olan isimlerin fetvâlarına muvâfik ya da muhâlif fetvalar verdiği de kaynaklarda sabittir. Buna ek olarak hem İbn Ömer hem de İbn Abbas ile birlikte kendilerine yöneltilen fikhî meselelere birlikte cevap verdiklerini gösteren örnekler mevcuttur. Bu durum, sahâbenin Ebû Hüreyre'nin fikhî meselelerdeki görüşlerini dikkate aldıklarının ve kendisini fakih olarak kabul ettiklerinin en önemli göstergelerinden birisidir. Ayrıca Takiyyüddîn es-Sübkînin kaleme aldı̆̆ı ve günümüze ulaştı̆̆ bilinmeyen hacmi bir cüz olan Fetâvâ Ebî Hüreyre isimli eseri de Ebû Hüreyre'nin sahâbenin fakihlerinden birisi olduğu tezini desteklemektedir.

Özellikle başta İsa b. Ebân olmak üzere bazı Hanefî fakihlerinin musarrât/muhaffele hadisiyle amel edilmemesini Ebû Hüreyre'nin fakih olmamasıyla temellendirmeleri yukarıda da gerekçeleri ortaya konulduğu üzere çok gerçekçi gözükmemektedir. Zira Ebû Hüreyre tarafından nakledilen rivayetin sıhhat açısından herhangi problemi olmadığı ehlinin tespitidir. Ayrıca bu rivayet, fikhî görüşleri Hanefî mezhebinin teşekkül ve gelişiminde önemli bir rol oynayan, üstelik fikıh alanında sahâbenin en fazla öne çıkan simalarından birisi olan İbn Mes'ûd tarafından da rivayet edilmiştir. Ne var ki, Hanefî fikıh kaynaklarında İbn Mes'ûd tarafından nakledilen bu rivayete ya yer verilmemiş ya da meçhul sîgayla İbn Mes'ud ismi zikredilmeksizin kaydedilmiştir. Hadisin İbn Ömer ve Enes b. Mâlik tariklerini de dikkate aldığımızda fikhu'r-râvi şartı ileri sürülerek rivayetin amel etmeye değer görülmemesinin problemli bir yaklaşım olduğu söylenebilir.

104 Serahsî, el-Mebsût, 11/134. 
Gerek tabakât müellifleri gerekse Hanefî mezhebi de dâhil farklı mezheplere mensup fakihlerin Ebû Hüreyre'nin sahâbenin fakihlerinden olduğuna yönelik açılamaları da bu noktada önem arz etmektedir. Elbetteki Ebû Hüreyre'nin fikıh nosyonu ve donanımı açısından Hz. Ömer, Hz. Ali, İbn Mes'ûd, Hz. Âişe, İbn Abbas (r.a.) gibi sahâbenin önde gelen fakihleriyle kıyaslanamayacağı bir gerçektir. Ancak bu onun fakih olmadığı anlamına gelmemektedir. Nitekim yukarıdaki örneklerde geçtiği üzere Hanefî fikıh kaynaklarında bile Ebû Hüreyre'nin vermiş olduğu fetva örneklerine rastlanmaktadır. Bu bile onun sahâbenin fakihlerinden biri olarak kabul edildiğine delil teşkil etmektedir.

Etik Beyan / Ethical Statement

Yazar / Author
Bu çalışmanın hazırlanma sürecinde bilimsel ve etik ilkelere uyulduğu ve yararlanılan tüm çalı̧̧maların kaynakçada belirtildiği beyan olunur/It is declared that scientific and ethical principles have been followed while carrying out and writing this study and that all the sources used have been properly cited.

Adem Çiftci

\section{Kaynakça}

Abdulazîz el-Buhârî. Keş̧ü'l-esrâr an Usûli Fahri'-İ́slam el-Pezdevî. Beyrut: el-Mektebetü'l-Asriyye, 2012. Abdürrezzâk. Ebû Bekr Abdürrezzâk b. Hemmâm b. Nâfi' es-San'ânî. el-Musannef. Beyrut: el-Mektebetü'l-İslâmî, 1983.

Acar, H. İbrahim. “Iddet”. Türkiye Diyanet Vakfi İslam Ansiklopedisi. 21/466-471. İstanbul: TDV Yayınları, 2000.

Ağırman, Cemal. "Müksirûn”. Türkiye Diyanet Vakfi İslam Ansiklopedisi. 31/534.İstanbul: TDV Yayınları, 2006.

Ahmed b. Hanbel. Müsned. thk. Şuayb el-Arnaût v. dğr. Beyrut: Müessesetü’r-Risâle, 1999.

Aynî, Bedreddin. el-Binâye şerhu'l-Hidâye. thk. Emîn Sâlih Şa'bân. Beyrut: Dâru'l-Kütübi'l-illmiyye, 2000.

Aynî, Bedreddin. Umdetü'l-kâri' şerhu Şahîhi'-Buhârî. Beyrut: Dâru'l-Kütübi'l-illmiyye, 2001.

Bedir, Murteza. Fikıh, Mezhep ve Sünnet. İstanbul: Ensar Neşriyat, 2004.

Belâzürî, Ebü'l-Abbas Ahmed b. Yahyâ b. Câbir. Fütûhu'l-büldân. Beyrut: Dâru Mektebeti'l-Hilâl, 1988.

Beyhakî, Ebû Bekr Ahmed b. el-Hüseyn b. Ali. es-Sünenü'l-kübrâ. thk. Muhammed Abdulkadir Atâ. Beyrut: Dâru'l-Kütübi'l-ilmiyye, 2003.

Buhârî, Ebû Abdullah Muhammed b. İsmail. el-Câmi u's'sahîh. thk. Muhyiddîn el-Hatîb. Kâhire: el-Matbatü's-Selefiyye, 1400/1980.

Cessâs, Ebû Bekir Ahmed b. Ali er-Râzî. el-Fusûl fi'l-usûl. thk. Uceyl Câsim Neşemî. İstanbul: Mektebetü'l-İrşâd, 1994.

Cüveynî, İmâmü'l-Haremeyn. Nihâyetü'l-matlab fi dirâyeti'l-mezheb. thk. Abdülazîm Mahmud ed-Dîb. Beyrut: Darü'l-Minhac, 2007/1428.

Debûsî, Ebû Zeyd Ubeydullah b. Muhammed. Takvîmü'l-edille fi usûli'l-fikh. thk. Halil Muhyiddîn elMeys. Beyrut: Dâru'l-Kütübi'l-ilmiyye, 2007.

Dihlevî, Şah Veliyyullâh. el-İnsâffí beyâni esbâbi'l-ihtilâf. Beyrut: Dâru'n-Nefâis, 1986.

Ebû Dâvud, Süleyman b. Eş‘as b. İshak es-Sicistânî el-Ezdî. es-Sünen. thk. Sıtkı Cemîl el-Attâr. Beyrut: Dâru'l-Fikr, 2001. 
Ebû Dâvûd, Süleyman b. Eş'as b. İshak es-Sicistânî el-Ezdî. Sünenü Ebî Dâvûd. thk. Şuayb el-Arnaût v.dğr. Beyrut: Dâru'r-Risâleti'l-Âlemiyye, 2009.

Ebû Dâvûd, Süleyman b. Eş'as b. İshak es-Sicistânî el-Ezdî. Sünenü Ebî Dâvûd. thk. Muhammed Muhyiddin Abdülhamîd. Beyrut: el-Mektebetü'l-Asriyye, ts.

Ebû Ubeyd, Kâsım b. Sellâm el-Herevî. Kitâbü'l-Emvâl. thk. Halil Muhammed Herrâs. Beyrut: Dâru'lFikr, ts.

Ebû Yûsuf, Yakub b. İbrâhîm. İhtilâfu Ebî Hanîfe ve İbn Ebî Leylâ. thk. Ebü'l-Vefâ el-Efgânî. b.y.: Matbaatü'l-Vefâ, 1357.

Ebû Yûsuf, Yakub b. İbrâhim. Kitâbül'-Âsâr. haz. Ebü'l-Vefâ el-Efgânî. Beyrut: Dâru'l-Kütübi'l-İlmiyye, ts.

Ebû Zehre, Muhammed. Ebû Hanîfe: Hayâtuhu ve asruhu-ârâuhu ve fikhuhu. Kâhire: Dârü'l-Fikri'l-Arabî, ts.

Ebü'l-Ali Muhammed Abdurrahman b. Abdurrahîm Mübârekpûrî, Tuhfetü'l-ahvezî. Dımaşk: Dâru'l-Fikir, ts.

Emir Padişah. Muhammed Emin b. Mahmûd Buhârî. Teysîrü't-tahrîr şerhu alâ Kitâbi't-tahrîr. Mekke-i Mükerreme: Dâru'l-Bâz, ts.

Hatîb, Muhammed Accâc. Ebû Hüreyre rivâyetü'l-İslâm. b.y.: Mektebetü Vehbe, 1982.

Hatîb, Muhammed Accâc. es-Sünne kable't-tedvîn. Beyrut: Dâru'l-Fikr, 1980.

Heysemî, Nureddin Ali b. Ebî Bekr. Mecme'u'z-zevâid ve menbe'u'l-fevâid. Beyrut: Dâru'l-Fikr, 1412.

İbn Abdülber, Ebû Ömer Cemaleddin Yûsuf b. Abdullah b. Muhammed Kurtubî en-Nemerî. el-İstizkâr. Beyrut: Dâru'l-Kütübi'l-i̇lmiyye, 2002.

İbn Asâkir, Ebü'l-Kâsım Alî b. el-Hasen b. Hibetillâh b. Abdillâh b. Hüseyn ed-Dımaşkî. Târihu Dımaşk. thk. Muhibbüddin Ebî Saîd Ömer b. Garâme el-Amrî. Beyrut: Dârü'l-Fikr, 1995/1415.

İbn Ebî Şeybe, Ebû Bekr Abdullah b. Muhammed b. İbrâhim. el-Musannef. thk. Ebû Muhammed Usâme b. İbrahim b. Muhammed. Kâhire: el-Fâruku'l-Hadîse, 2007.

İbn Emîru Hâc, Ebû Abdillâh Şemsüddîn Muhammed b. Muhammed b. Muhammed el-Halebî. et-Takrîr ve'ttahbîr. Beyrut: Dâru'l-Kütübi'l-illmiyye, 1999.

İbn Hacer el-Askalânî, Ebü'l-Fazl Şihâbüddîn Ahmed b. Alîb. Muhammed. el-ìsâbe fitemyizi's-sahâbe. thk. Adil Ahmed Abdülmevcud-Ali Muhammed Muavvaz. Beyrut: Dâru'l-Kütübi'l-illmiyye, 1995.

İbn Hacer el-Askalânî, Ebü'l-Fazl Şihâbüddîn Ahmed b. Alî b. Muhammed. Fethü'l-bârî Şerhu Sahîhi'-Buhârî. Beyrut: Dâru'l-Ma'rife, 1379.

İbn Hazm, Ebû Muhammed Ali b. Ahmed b. Saîd. el-ìhkâm fí usûlil'-ahkâm. thk. Mahmud Hamid Osman. Kâhire: Dâru'l-Hadîs, 2005.

İbn Kayyim el-Cevziyye, Ebû Abdullah Şemseddin Muhammed. İlâmu'l-muvaki în an Rabbi'l-âlemîn. thk. Muhammed Abdüsselam İbrâhim. Beyrut: Dârul'-Kütübi'l-illmiyye, 1991/1411.

İbn Mâce, Ebû Abdullah Muhammed b. Yezid er-Rebeî el-Kazvînî. Sünenü İbn Mâce. thk. Halil Me'mûn Şîhâ. Beyrut: Dârü'l-Ma'rife, 1996/1416.

İbn Nüceym, Zeynüddin b. İbrâhim b. Muhammed. Fethu'l-ğaffâr bi șerhil-Menâr. Mısır: Şerikatü Mektebetü ve Matbaatü Mustafa, 1936.

İbn Sa'd, Ebû Abdullah Muhammed b. Sa'd b. Menî‘ ez-Zührî. et-Tabakâtu'l-kübrâ. thk. Ali Muhammed Ömer. Kâhire: Mektebetü'l-Hancı, 2001.

İbnü'l-Hümâm, Kemâlüddîn Muhammed b. Abdilvâhid b. Abdilhamîd es-Sivâsî el-İskenderî. et-Tahrîr fi usûli'l-fikh. Mısır: Matbaatü Mustafa el-Bâbî el-Halebî, 1351.

İzmirli, İsmail Hakkı. İlm-i Hilâf. haz. Sırrı Fuat Ateş. Konya: Hüner Yayınevi, 2012.

Kal'âcî, Muhammed Ravvâs. Mevsû́atü fikhi Abdillâh b. Ömer. Beyrut: Dâru'n-Nefâis, 1986.

Kanarya, Bayram. “Ebû Reyye'nin Bazı Temel Hadis Meseleleri İle İlgili İddialarına İbn Yahya'nın Verdiği Cevaplar". Dicle Üniversitesi Sosyal Bilimler Enstitüsü Dergisi. 16 (2016), 150-171.

Kandemir, M. Yaşar. "Ebû Hüreyre”. Türkiye Diyanet Vakfi İslam Ansiklopedisi. 10/160-167. İstanbul: TDV Yayınları, 1994.

Kandemir, M. Yaşar. “Abdullah b. Ömer b. el-Hattâb”. Türkiye Diyanet Vakfi İslam Ansiklopedisi. 1/126-128. İstanbul: TDV Yayınları, 1988.

Karâfî, Şihâbuddîn Ahmed b. İdris. ez-Zehîra. thk. Muhammed Haccî. Beyrut: Dâru'l-Garbi'l-ïslâmî, 1994. 
Kârî, Ebü'l-Hasan Nureddin Ali b. Sultan Muhammed Ali. Şerhu Müsnedi Ebî Hanîfe. thk. Halil Muhyiddin elMeys. Beyrut: Dâru'l-Kütübi'l-ìlmiyye, 1985.

Kâsânî, Alâüddîn. Bedâi'u's-sanâi fi tertîbi'ş-şerâit. Beyrut: Dâru'l-Kütübi'l-Arabî, 1982.

Kâtib Çelebi, Hacı Halife Mustafa b. Abdullah. Süllemü'l-vüsûl ilâ tabakâti'l-fuhûl. thk. Mahmud Abdülkadir elArnaût. İstanbul: Ma'hedü'l-Buhûs ve'd-Dirâsati'l-Arabiyye/IRCICA, 2010.

Kettânî, Muhammed Abdülhay b. Abdilkebîr b. Muhammed Hasenî İdrîsî. Nizamü'l-hükümeti'n-nebeviyye: etTerâtibü'l-idâriyye. thk. Abdullah el-Hâlidî. Beyrut: Dâru'l-Erkâm, ts.

Kettânî, Muhammed Abdülhay b. Abdilkebîr b. Muhammed Hasenî İdrîsî. et-Terâtibüll-idâriyye: Hazreti Peygamber'in Yönetiminde Sosyal Hayat ve Kurumlar. çev. Ahmet Özel. İstanbul: İz Yayıncıllk, 1993.

Kudûrî, Ebü'l-Hüseyin Ahmed b Ebî Bekr Muhammed b Ahmed. Mevsû'atüll-kavâidil-fikhiyyeti'l-mukârene: etTecrîd. thk. Muhammed Ahmed Sirac, Ali Cum'a Muhammed. Kâhire: Dârü’s-Selâm, 2004.

Kureşî, Ebû Muhammed Muhyiddin Abdülkadir b. Muhammed. el-Cevâhirü'l-mudiyye fî tabakâti'l-Hanefiyye. thk. Abdülfettah Muhammed el-Hulv. Kâhire: Dâru'l-Hicr, 1993.

Leknevî, Abdülali Muhammed b. Nizameddin Muhammed Sehâlevî el-Ensârî. Fevâtihü'r-rahamût bi-şerhi Müsellemi's-sübût. Beyrut: Dâru'l-Kütübi'l-İlmiyye, 2002.

Mâlik b. Enes. el-Muvatta'. Dubâi: Mektebetü'l-Furkân, 2003.

Mâlik b. Enes. Muvatta rivâyetü Muhahammed b. el-Hasan eş-Şeybânî. thk. Abdülvehhâb Abdullatîf. Kâhire: elMektebetü'l-ìlmiyye, 1994.

Muallimî, Abdurrahman b. Yahya el-Yemânî. el-Envârü'l-kâşife limâ fi kitâbi edva ale's-sünne mine'z-zelel ve'ttadlîl ve'l-mücâzefe. Beyrut: Alemü'l-Kütüb, ts.

Müslim b. el-Haccâc, Ebü'l-Hüseyin el-Kuşeyrî en-Neysâbûrî. el-Câmi'u's-sahîh. thk. Halil Me'mûn Şîhâ. Beyrut: Dâru'l-Ma'rife, 2005.

Öğüt, Salim. İslam Hukuk Metodolojisinde Haber-i Vâhid’in Kaynak Değeri. İstanbul: Ocak Yayıncılık, 2003.

Özafşar, M. Emin-Demir, Mahmut. “Zayıf”, Türkiye Diyanet Vakfi İslam Ansiklopedisi. 44/157-160. İstanbul: TDV Yayınları, 2013.

Özen, Şükrü. “İsa b. Ebân”. Türkiye Diyanet Vakfi İslam Ansiklopedisi. 22/480-481. İstanbul: TDV Yayınları, 2000. Ebû Reyye, Muhammed. Şeyhu'l-madîre Ebû Hureyre. Kâhire: Dâru'l-Maârif, ts.

Ebû Reyye, Muhammed. Edvâ' ale's-sünneti'l-Muhammediyye ev difấ 'ani'l-hadîs. Beyrut: Müessesetü'l-Âlemî, 1957.

Sadrüşşerîa, Ubeydullah b. Mes'udb. Mahmûd el-Buhârî el-Mahbûbî. et-Tavdîh ale't-Tenkîh. thk. Saîd el-Ebraş. Dımaşk: Mektebetü Merzûk, 2006.

Sem ‘ânî, Ebü'l-Muzaffer Mansûr b. Muhammed b. Abdilcebbâr Temîmî Mervezî. Kavâtiül-edille fi'l-usûl. thk. Muhammed Hasan İsmail eş-Şâfiî. Beyrut: Dâru'l-Kütübi'l-ìlmiyye, 1997.

Serahsî, Şemsüleimme Ebû Sehl Ebû Bekir Muhammed b. Ahmed. el-Mebsût. Beyrut: Dâru'l-Ma'rife, ts.

Serahsî, Şemsüleimme Ebû Sehl Ebû Bekir Muhammed b. Ahmed. el-Usûl. thk. Ebu'l-Vefa el-Efgânî. Beyrut: Dâru'l-Kütübi'l-ìlmiyye, 1973.

Suyûtî, Ebü'l-Fazl Celaleddin Abdurrahman b. Ebî Bekr. Tedrî̉ü’r-râvîfi şerhi Takrîbi’n-Nevevî. thk. Abdülvehhab Abdüllatif. Riyâd: Mektebetü'r-Riyâd, ts.

Şa'rânî, Abdülvehhab. Kitâbü'l-Mîzân. thk. Abdurrahman Umeyre. Beyrut: Âlemü'l-Kütüb, 1989.

Şâtıbî, Ebû İshak İbrâhim b. Musa b. Muhammed el-Gırnâtî. el-Muvâfakât. Kâhire: Dâru'l-Hadis, 2006.

Şeybânî, Muhammed b. Hasan. Kitabu'l-Hucce ale ehli Medîne. Beyrut: Âlemü’l-Kütüb, 1403.

Şeybânî, Muhammed b. Hasan. Kitâbü'l-Asl: el-Mebsût. thk. Ebü'l-Vefâ el-Efgânî. Beyrut: Âlemü'l-Kütüb, 1990. Şeyh, Abdüssettâr. Ebû Hüreyre rivâyetül-İslâm ve seyyidü'l-huffâzi'l-esbât. Dımaşk: Dârü'l-Kalem, 2003.

Şîrâzî, Ebû İshâk Cemâlüddîn İbrâhîm b. Alî b. Yûsuf. Tabakâtü'l-fukahâ. thk. İhsan Abbas. Beyrut: Dâru'r-Râid el-Arabî, ts.

Tahâvî, Ebû Ca'fer Ahmed b. Muhammed b. Selâme Ezdî Hacrî Misrî. Şerhu Me âni'l-âsâr. thk. Muhammed Seyyid Ca'delhak, Muhammed Zührî en-Neccâr. Beyrut: Alemü'l-Kütüb, 1994.

Tirmizî, Ebû İsa Muhamed b. İsa b. Sevre es-Sülemî. el-Câmi'u's-sahîh. thk. Halil Me'mûn Şîhâ. Beyrut: Dâru'lMa'rife, 2002.

Tsılıgkır, Chamntı. "Hanefîlere Göre Haberin Kıyasa Aykırı Olması Durumunda Râvinin Fakih Olma Şartı". Sakarya Üniversitesi İlahiyat Fakültesi Dergisi. 21/1 (2010), 69-83. 
Ünal, İsmail Hakkı. Imam Ebû Hanîfe' nin Hadis Anlayışı ve Hanefî Mezhebinin Hadis Metodu. Ankara: Diyanet İşleri Başkanlığı Yayınları, 2012.

Yaman, Ahmet. “Abdullah b. Mes'ûd'un Hanefî Mezhebinin Oluşumundaki Rolü”. Mârife. 4/2 (2004), 9-26.

Yarba, Rıdvan. “Tartışmalı Bazı Hadisleri ve Fetvaları Bağlamında Ebû Hüreyre'nin Fakihliği Meselesi”. İslam Medeniyetinin Kurucu Nesli Sahâbe -Sahâbe ve Dirâyet İlimleri- III. ed. Abdullah Aydınlı v.dğr. İstanbul: Ensar Neşriyat, 2018.

Yiğit, Metin. Ebû Hanîfénin Usûl Anlayışında Sünnet. İstanbul: İz Yayıncıllk, 2009.

Zehebî, Şemseddin Muhammed b. Ahmed b. Osman. Siyeru a'lâmi’n-nübelâ. thk. Beşşar Avvad Ma'ruf. Beyrut: Müessesetü'r-Risâle, 1996.

Zehebî, Şemseddin Muhammed b. Ahmed b. Osman. Tezkiratü'l-huffâz. Haydârabâd: Matbaatü Meclisi Dâirati'l-Maârifi'n-Nizamiyye, 1333.

Zerkeşî, Ebû Abdullah Bedreddin Muhammed b. Bahadır b. Abdullah. Hz. Âişénin Sahâbeye Yönelttiği Eleştiriler. çev. Bünyamin Erul. Ankara: Kitabiyât, 2008.

Zerkeşî, Ebû Abdullah Bedreddin Muhammed b. Bahadır b. Abdullah. el-Bahru'l-muhît fî usûli'l-fikh. haz. Abdülkadir Abdullah el-Ânî. Kuveyt: Vizaretü'l-Evkâf ve'ş-Şuuni'l-i̇slâmiyye, 1992.

Zeylaî, Ebû Muhammed Cemâlüddîn Abdullah b. Yûsuf b. Muhammed. Nasbu'r-râye li tahrîci ehâdisi'l-Hidâye. Cidde: Müessesetü'r-Reyyân, ts.

Zürkânî, Ebû Abdullah Muhammed b. Abdülbaki b. Yûsuf. Şerhu’z-Zürkânîalâ Muvattai İmam Mâlik. thk. Taha Abdurrauf Sa'd. Kâhire: Mektebetü’s-Sekâfeti'd-Dîniyye, 2003/1424. 